\title{
Mesozoic Tectono-Thermal Event of the Qinshui Basin, Central North China Craton: Insights From Illite Crystallinity and Vitrinite Reflectance
}

\author{
Runchuan Liu ${ }^{1,2,3,4}$, Zhanli Ren ${ }^{2 *}$, Peng Yang ${ }^{2 *}$, Huaiyu He ${ }^{1,3,4}$, Thomas M. Smith ${ }^{1,3,4}$, \\ Wei Guo ${ }^{1,3,4}$ and Lin Wu ${ }^{1,3,4}$
}

${ }^{1}$ State Key Laboratory of Lithospheric Evolution, Institute of Geology and Geophysics, Chinese Academy of Sciences, Beijing, China, ${ }^{2}$ State Key Laboratory of Continental Dynamics, Department of Geology, Northwest University, Xi'an, China, ${ }^{3}$ Institutes of Earth Science, Chinese Academy of Sciences, Beijing, China, ${ }^{4}$ College of Earth and Planetary Sciences, University of Chinese Academy of Sciences, Beijing, China

OPEN ACCESS

Edited by:

Kai-Jun Zhang,

University of Chinese Academy of

Sciences, China

Reviewed by:

Kun Yu,

Chinese Academy of Sciences (CAS),

China

Hongjian Zhu,

Yanshan University, China

*Correspondence:

Zhanli Ren

Renzhan/@nwu.edu.cn

Peng Yang

p.yang@nwu.edu.cn

Specialty section: This article was submitted to

Geochemistry,

a section of the journal

Frontiers in Earth Science

Received: 27 August 2021 Accepted: 27 September 2021

Published: 25 October 2021

Citation:

Liu R, Ren Z, Yang P, He H, Smith TM, Guo $W$ and $W u L$ (2021) Mesozoic

Tectono-Thermal Event of the Qinshui Basin, Central North China Craton: Insights From Illite Crystallinity and Vitrinite Reflectance.

Front. Earth Sci. 9:765497. doi: 10.3389/feart.2021.765497
The Qinshui Basin is in the Central Orogenic Belt of the North China Craton (NCC), and the production of coalbed methane accounts for $70 \%$ of China's total coalbed methane output. Aiming at the unclear dynamic causes of large-scale coalbed methane accumulation in the basin and the unclear response relationship with the destruction of the NCC, we present joint illite crystallinity and vitrinite reflectance study across the Zijin Mountain and Qincan 1 wells of the Qinshui Basin, respectively. Inverse modeling suggested that tectono-thermal events occurred during the Early Cretaceous, associated with the maximum burial depth and heat flow. The maximum paleogeothermal temperature and gradient reconstruction results recorded at the Carboniferous strata are $180-190^{\circ} \mathrm{C}$ and $6.5^{\circ} \mathrm{C} / 100 \mathrm{~m}$. The denudation thicknesses recorded by illite crystallinity of Zijinshan and the vitrinite reflectance of the Qincan 1 Well are 3,180.63 m and 3,269.32 m, respectively. We propose that the Qinshui Basin was affected by the extensional environment of the NCC, which caused deep lithospheric thinning and magma upwelling, and a tectono-thermal event occurred during the Early Cretaceous in Qinshui Basin. In addition, the accumulation of coalbed methane, triggered by a tectono-thermal event during the Early Cretaceous, is consistent with the early Cretaceous accumulation and mineralization events in the NCC. Overall, our results reflect the subduction event influence of the western Pacific plate into the East Asian continental plate on the tectono-thermal history of the Central Orogenic Belt of the NCC, which is theoretically significant for clarifying the thermal lithospheric thickness and rheological structure of the basin, as well as the evolutionary history of coalbed methane, and the basin response relationship to the destruction of the NCC.

Keywords: Qinshui Basin, North China Craton, Tectono-thermal event, Illite, Basin modeling

\section{INTRODUCTION}

Structurally, the Qinshui Basin belongs to the Shanxi block in the center of the North China Craton (NCC) (He, 2015; Zhu et al., 2015). It is one of the areas with the most abundant coal resources within the NCC, and the production of coalbed methane ranks first in China. At present, there are about 11,000 coalbed methane wells in the basin, accounting for more than $70 \%$ of the total number 
of coalbed methane drilling wells in China, making it one of China's most important energy sources (Zhao et al., 2016; Li Z. et al., 2018, Li et al., 2018 R.).

During the late Mesozoic, the NCC has experienced intense transformation and destruction, and the early Cretaceous was a critical period of lithospheric thinning and destruction for the eastern NCC (Li et al., 2012b). Numerous studies, therefore, focused on the spatial distribution of the transformation and of the destruction of the NCC (Zhang et al., 2006; Zhang, 2012; Zhu et al., 2015; Meng et al., 2019; Liu, 2020). Up to now, the timing, the spatial range, the specific process, and the dynamic mechanism of lithospheric thinning and destruction have been investigated (Ying et al., 2011; Zhu et al., 2012, 2014, 2017; Zhu and Xu, 2019; Zhai et al., 2020, 2021a, 2021b). The range of destruction of the NCC is thought to be limited to only the eastern region. However, additional evidence shows that the lithospheric thickness in the central and western parts of the NCC varies greatly (Chen, 2009; Chang et al., 2011; Ling et al., 2017), indicating that the thinning and reformation of the lithospheric mantle also occurred in the central and western NCC, but the influence of destruction event on the Qinshui Basin remains unclear.

Due to the limited spatial distribution of mantle xenoliths and magmatic rocks, the research on lithospheric thinning and the evolution history of the Ordos Basin in the western part of the NCC is limited, and the research on whole strata of the Qinshui Basin in the central part is even weaker. It is still under debate whether there is excessive thinning of lithosphere and cratonic destruction in the central (Qinshui Basin) and western (Ordos Basin) parts of the NCC (SongLin et al., 2011; Zhu et al., 2012; Ling et al., 2017; Xinhui et al., 2017; Liu, 2020). In addition to abnormal changes in the geothermal field, which can to a certain extent reveal the process of deep lithospheric activity, the tectonothermal history during the Mesozoic and Cenozoic in the basin and the restoration of the paleotemperature field are the keys to recovering the thermal structure of the lithosphere in different periods. In other words, the tectono-thermal history of different parts of the Qinshui Basin needs to be accurately described and compared to improve the understanding of its tectono-thermal history, which is directly related to the generation, migration, and accumulation processes of coal/gas and the evaluation of the mature evolution of the organic matter.

To date, many petroleum geologists have focused on the tectonic uplift history, thermal evolution history, and coalbed methane of the Qinshui basin, suggesting that the Qinshui Basin was affected by the destruction of the NCC, which caused a tectonic thermal event in the basin during the Early Cretaceous, prompting the rapid over-maturation of source rocks and the production of coalbed methane (Ren et al., 2005; Sun et al., 2005; Ren et al., 2006; Sun et al., 2006; Wei et al., 2007; Meng et al., 2015a, 2015b; Sun et al., 2018; Meng et al., 2019; Yu et al., 2020a; Ren et al., 2020). It has been demonstrated by hydrocarbon explorations that a large amount of coalbed methane was preserved in the north and south parts of the basin. All of these past works provide a very important foundation for our research. In addition, the study of both the geothermal field and the thermal structure of the lithosphere is an effective way to examine the deep geodynamics and the evolution of the craton. Strengthening the study of geothermal events in The Qinshui Basin in the Early Cretaceous is not only of great theoretical significance to improve the understanding of the dynamic evolution mechanism of the lithosphere in NCC, but it is also of great practical significance to mineralization research, reservoir-forming, and the exploration of coal, coalbed methane and other mineral resources in the Qinshui Basin of the central NCC. Recently, geologists and industry paid close attention to the dynamic evolution of the lithosphere and its relationship with mineral accumulation (mineralization) in the central and western parts of the NCC.

The purpose of this study is to reveal the tectonic thermal evolution history and its deep mechanism of different strata, and to discuss the response relationship with basin hydrocarbon source generation and the NCC craton destruction, using the paleotemperature scale and a standard basin modeling procedure. Therefore, in this work, an integrated method combining the illite crystallinity, vitrinite reflectivity, and Basin Mod 1D is proposed to improve the understanding of the thermal history of the formation in the central Qinshui basin. For such a purpose, we systematically collected, tested, and analyzed samples from different layers in the central basin, combined with vitrinite reflectance $\left(R_{\mathrm{o}}\right)$ data from different layers in Well Qincan 1 . Based on our data, we obtained a comprehensive reconstruction of the thermal history of different stratum in the central basin, which is of theoretical significance for clarifying the thermal lithospheric thickness and rheological structure of the basin, as well as the evolution history of coalbed methane, and the basin response relationship to the destruction of the NCC.

\section{GEOLOGICAL SETTING}

The intracratonic NCC is located between the Central Asian Orogen Belt (CAOB) and the Central China Orogenic Belt (CCOB), and by convention, the NCC has been subdivided into the West Block, Eastern Block, and the Trans-North China Orogen (Zhao et al., 2009, 2001) (Figure 1). Variably exposed Archean to Paleoproterozoic rocks compose the basement of the NCC, it is unconformably overlaid on the Mesoproterozoic unmodified volcano-sedimentary sequence and Phanerozoic caprock (Shanxi, 1989). Archean stratigraphy is represented by strata of the Wutai Group and Huping Group, dominated by Tiebao movement and forms a lithology represented by schist, gneiss, marble, and migmatite, whereas Proterozoic stratigraphy consists of schist, gneiss, sandstone, powder sandstone, and mud shale, from bottom to top. The early Paleozoic strata in the Qinshui Basin are mainly represented by the Cambrian-Middle Ordovician thick carbonate rocks, including argillaceous limestone, oolitic limestone, dolomite, and other huge thick deposits, and a large-scale unconformity denudation event was experienced between the Middle Ordovician and the Early Carboniferous, leading to the absence of the Silurian, Devonian, and part of the Early Carboniferous strata. Late Carboniferous to Early Permian alternate marine and terrestrial sequences, and is 


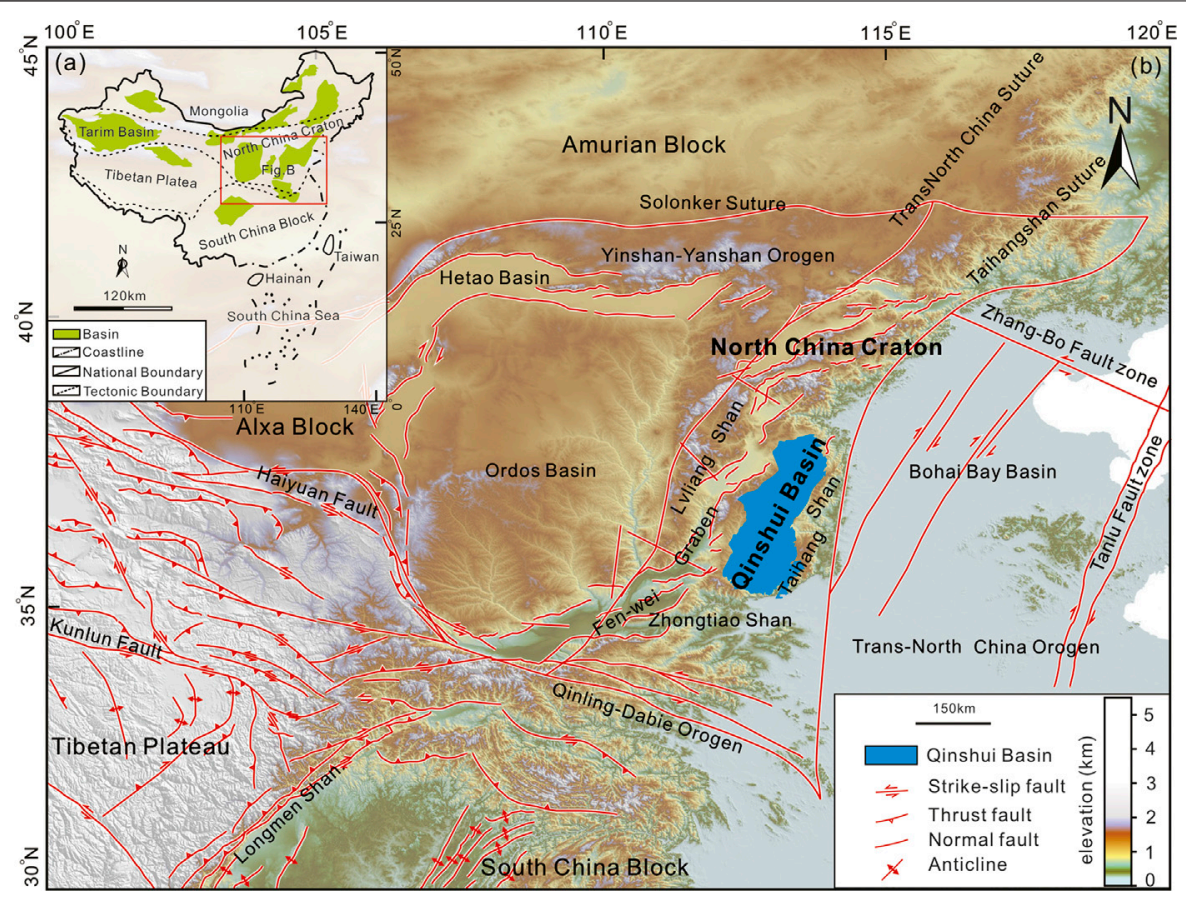

FIGURE 1 | Geological Setting of Qinshui Basin (A) Tectonic and basin map of China. Structures are modified from (Yang et al., 2018, 2021a) (B) Regional topographic and neotectonic map of North China. Structures are modified from Ye et al. (1987); Deng et al. (1987); Qi and Yang, (2010), Zhang et al. (2019), and Su et al. (2021). Red boxes show the location of the study areas. (B) Distribution map of North China Craton and Qinshui Basin.

characterized by coal-bearing strata, overlaid by the Late Permian to Triassic red beds and conglomerates (Shanxi, 1989; Zhu et al., 2014).

The Qinshui Basin is located in the south-central part of the Trans-North China Orogen, surrounded by the Taihang Mountains in the east, the Huo Mountains in the west, the Zhongtiao Mountains in the south, and the Wutai Mountains in the north (Cai et al., 2011) (Figure 2). The crust of the study area is relatively thin, and the strata of Paleozoic are widely exposed around the basin while the Mesozoic strata are exposed in the center part of the basin. Besides, the provenance of the strata is extensive, the tectono-thermal history of the Qinshui Basin is complex, and the stratigraphic denudation discontinuity is obvious and its development experienced multi-cyclic tectonic-sedimentary evolution (Cai et al., 2011; Li et al., 2012a; Zhu et al., 2014; Chen et al., 2018). It is an ideal place to study the tectonothermal history of the south-central NCC during the Paleozoic and Mesozoic (Figure 1; Figure 2).

\section{SAMPLING AND METHODOLOGY}

\section{Sample Collection and Preparation}

To investigate the tectono-thermal history and denudation thickness of the Qinshui Basin, we collected the vitrinite reflectance data of the Qincan 1 well from PetroChina Huabei Oilfield Company, the vitrinite reflectance was tested with the same methods as described in Yu et al. (2020a) (Table 3); note that the abnormal high reflectance of vitrinite near the unconformity of the Carboniferous and Ordovician strata has been eliminated.

We also collected mudstones and shale stones from the western edge of the basin to the center of the basin to purify illite (Figures 2, 3). We sampled unaltered outcrops of fresh rocks in the elevated area to maximize the relief wherever lithology and access were permitted. All samples collected in this work are Permian-Jurassic mudstones at an elevation ranging from 956 to 1,680 m (Supplementary Table S1; Figure 2). All the samples were analyzed for XRF to calculate the illite crystallinity and relative content of clay minerals and analyzed at the Exploration and Development Research Institute of Daqing Oilfield (China National Petroleum Corporation), China.

\section{Scanning Electron Microscopy Analysis}

Polished thin sections were made from representative samples for microscopic observation. To further identify the clay minerals and composition of the illite structure, scanning electron microscopy (SEM) observations and energy dispersive spectrometry (EDS) analyses were carried out with an acceleration voltage of $15 \mathrm{kV}$ and a working distance of $10 \mathrm{~cm}$ at the Electron Microprobe Analysis and Scanning Electron Microscope Laboratory of the Institute of Geology and Geophysics, Chinese Academy of Sciences (IGGCAS). To obtain high-quality images, the polished samples were coated with $8 \mathrm{~nm}$ carbon before analysis. 


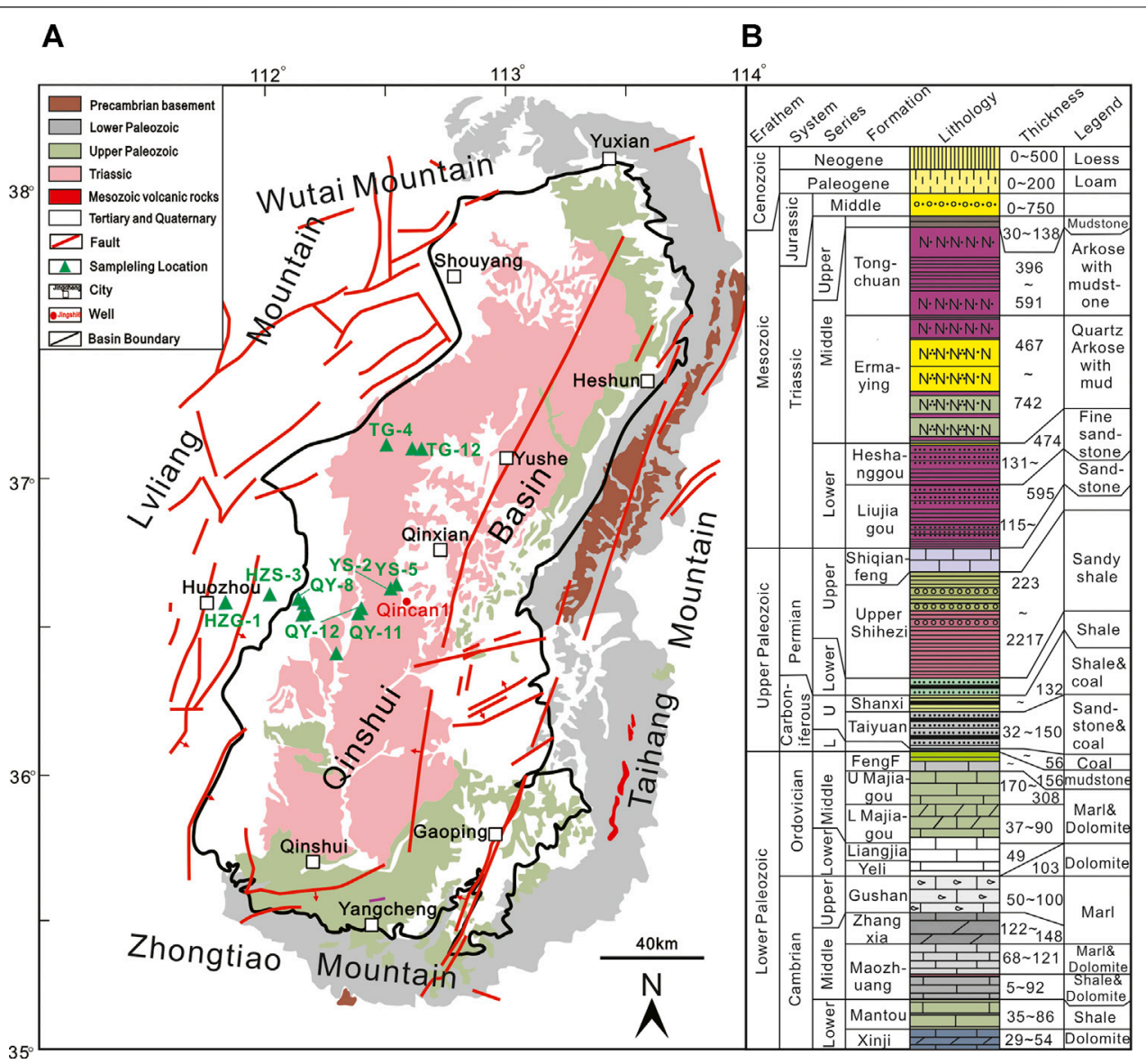

FIGURE 2 | (A) Sample location in Qinshui Basin, includes crack, well location, and city location. Structures modified from Meng et al. (2015), Zhu et al. (2014). (B) Regional stratigraphy column of the Cambrian-Cenozoic strata in the Qinshui Basin (Shanxi, 1989; Zhu, 2013; Zhu et al., 2014; Li Z. et al., 2018; Liu, 2020).

\section{XRD Analysis}

To achieve illite XRD analysis tests, the mudstone, siltstone, and calcareous mudstone samples needed to be $\sim 150 \mathrm{~g}$ with more than $40 \%$ clay content. We chose clay-rich samples (argillaceous siltstone, silty mudstone, mudstone, etc.,.) and crushed them to the diameter of $0.5-1 \mathrm{~cm}$ with a hammer; we subsequently used a DF-4 hammer crusher to crush the samples for less than $30 \mathrm{~s}$. We used the Stock method to collect $40 \mathrm{mg}$ of particles having diameter $<2 \mu \mathrm{m}$ and removed the liquid in suspension using an LXJ-64-1 centrifuge (Kisch, 1987; H.J.; Kisch, 1990).

We prepared the Oriented Clay Tablets by Precipitation Method with density $>3 \mathrm{mg} / \mathrm{cm}^{2}$ and dried the tablets naturally at room temperature (Kisch, 1987; H.J.; Kisch, 1990). We carried out the ethylene glycol expansion experiment at $50^{\circ} \mathrm{C}$, then according to the clay minerals contained in the sample, we heated the sample at $500^{\circ} \mathrm{C}$, the precision on the temperature of the muffle furnace used for heating is $\pm 2^{\circ} \mathrm{C}$. The experimental instrument is the Rigaku D/max$2200 \mathrm{X}$ diffractometer, with the following measurement parameters: $40 \mathrm{kV}$ voltage, $40 \mathrm{~mA}$ current, $\mathrm{Cu}$ target, $1 / 2^{\circ}$ emitting slit, $5.5 \mathrm{~mm}$ receiving slit, $0.04^{\circ}$ Soller slit, scanning step length of $0.017^{\circ} \Delta 2 \theta$, and scan time of the $20 \mathrm{~s}$ by $\mathrm{X}$ ' Celerator detector. The scanning range for mineral phase and polytype identification is $4-60^{\circ} \Delta 2 \theta$. The test range of crystallinity of illite and chlorite for oriented flake is $2.6-15^{\circ} \Delta 2 \theta$.

\section{RESULTS}

\section{Clay Mineral Assemblage}

Through the X-ray diffraction analysis of the sample, we can determine the dominant authigenic clay mineral assemblages in each stratigraphic unit (Supplementary Table S2). The clay minerals in the Triassic, Jurassic, Permian, and Cambrian strata in the central area of the Qinshui Basin are dominated by illite, and the combination of clay minerals is $\mathrm{I}+\mathrm{C}+\mathrm{K}$. The interlayer ratio of $\mathrm{I} / \mathrm{S}$ disorder is high, and illite accounts for $70-90 \%$. The clay mineral assemblage in the Carboniferous strata is dominated by kaolinite, and the clay mineral assemblage is $\mathrm{I}+\mathrm{C}+\mathrm{K}$ with the high interlayer ratio of I/S disorder, and illite accounts for $80-90 \%$ (Figure 4; Figure 5A).

According to Figure 5, there is a high illite content in each layer, most samples account for $50-80 \%$ of the total content of clay minerals (Figure $\mathbf{5 A}$ ), and the illite proportion in the shallow layer is higher than that the deep layer (Figure 5B), which may be caused by the sample difference. Kaolinite and the I/S mixed layer account for less than $30 \%$ of clay minerals. As the burial depth increases, kaolinite will turn into chlorite when the medium changes from acidic to alkaline (Gao et al., 2020; Zhu et al., 2021). The I/S trend of different layers stays stable, but the proportion of illite is high, indicating the high TTI (Time-Temperature Indicator) of the 

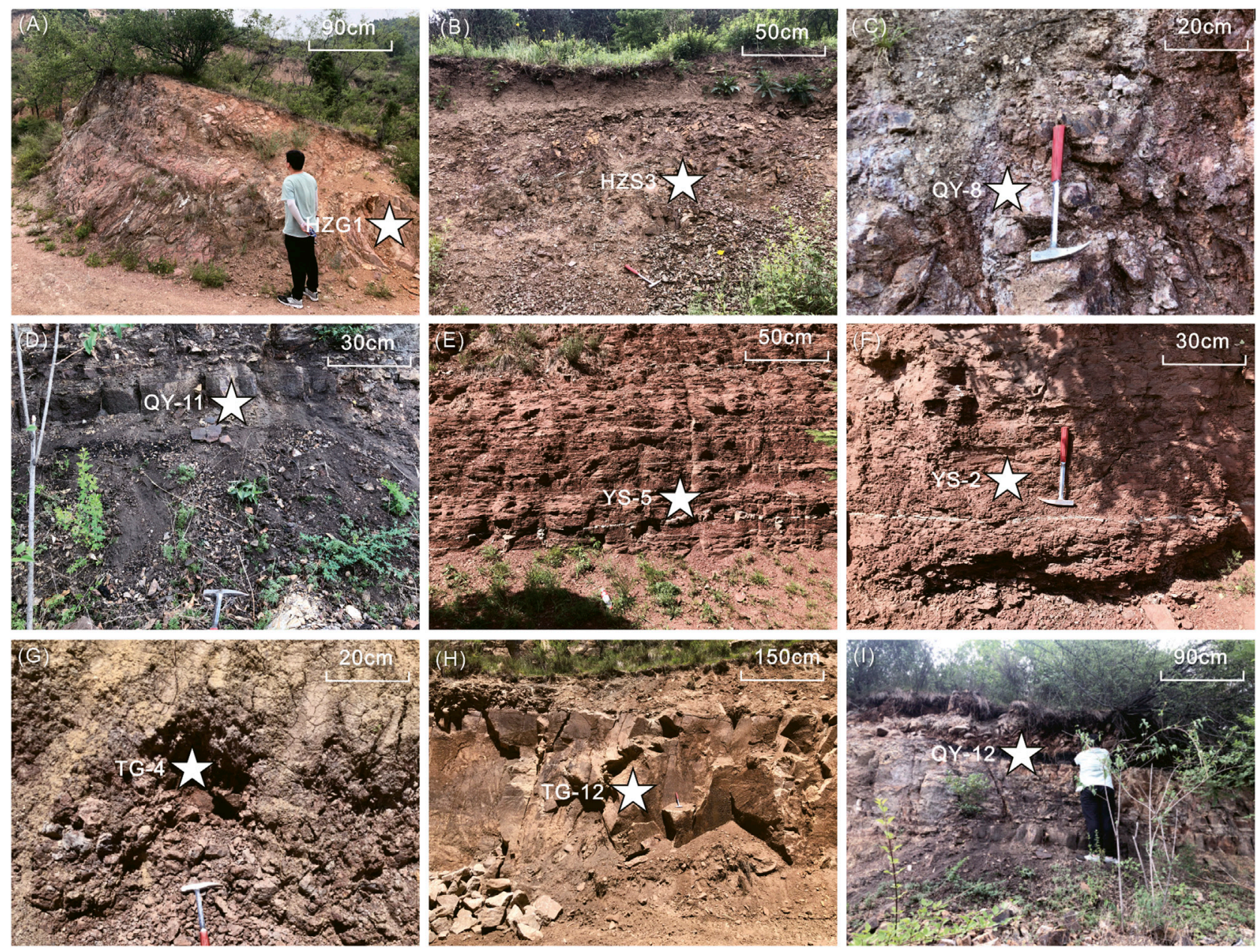

FIGURE 3 | Geological profile of the Qinshui Basin. (A) Dark purple red shale of Guanjiashan, Guanjialiang village, Huozhou (B) Cambrian Mantou formation shale in East Qiliyu village, Huozhou (C) Maroon ferruginous claystone of the Carboniferous Hutian section, Huozhou (D) Gray black mud shale of the Shihezi Formation in Donggou, Qinyuan (E) Purple-red mudstone in the Triassic Heshanggou formation, Qinyuan (F) Sandy mudstone in the Triassic Liujiagou formation, Qinyuan (G) Fuchsia mudstone of the Jurassic Ruqu formation, Zijinshan (H) Hujiacun Stage of Yanchang Formation, Zijinshan (I) Gray-black silty mudstone of the Permian Shihezi 1-2 Formation, Qinyuan.

study area (Figure 5B) (Ramseyer and Boles, 1986). The distribution of clay mineral content shows that the basin has experienced a high paleogeothermal evolution process.

Through SEM observation (Figure 6 and Supplementary Material), except for the upper Paleozoic Carboniferous Hutian section, the interlayer illite of mudstone and sandy mudstone in other layers is the main clay mineral of most samples. Illite associated with illite/smectite (I/S) and illite without I/S can be observed in different horizons, we can identify illite in four forms according to microstructure: (1). Strip illite associated with I/S (Figure 6A). (2). Feather and filamentous illite associated with I/S (Figure 6D). (3). Feather and Bridge illite (Figure 6E). (4). Rosette illite (Figure 6I).

The illite energy spectrum is characterized by $\mathrm{Al} / \mathrm{Si}$ ratio is close to 0.8 and high $\mathrm{K}$ content, and the main elements are $\mathrm{O}, \mathrm{Al}, \mathrm{Si}$, and $\mathrm{K}$, and the K/Al ratio is close to 0.4 (Uysal, 2000; Uysal et al., 2000, 2001, 2006; Zhu et al., 2021). I/S ( $\mathrm{R}=3$ ) mainly appears in the form of cotton floc (Figures 6A,G), and its energy spectrum is characterized by $\mathrm{K} / \mathrm{Ca}$ content close to 0.5 and $\mathrm{Al} / \mathrm{Si}$ ratio close to 0.5 (More details in the Supplementary material). Chlorite mainly occurs in the Shihezi Formation of Upper Paleozoic and Heshanggou formation of Lower Triassic of Mesozoic. Leaf-like (Figure 6C) and needle/layered liked chlorite can be observed, and its energy spectrum is characterized by high $\mathrm{Fe}$ content, and the $\mathrm{Fe} / \mathrm{Si}$ ratio is greater than 0.5 (Figure 6F). Kaolinite is mainly observed in the maroon iron clay rock of the upper series of the Hutian section of the Carboniferous in the upper Paleozoic, and it is hard to find kaolinite in the other horizons, which is in the form of vermicular porous (Figure 6B), and its energy spectrum characteristics show that the elements only contain $\mathrm{O}, \mathrm{Al}$, and $\mathrm{Si}$, with $\mathrm{Si} / \mathrm{O} \sim 1$, the $\mathrm{Si} / \mathrm{Al} \sim 0.8$ (More details in the Supplementary material). It can be observed that kaolinite rarely contains other clay mineral components (Uysal, 2000; Uysal et al., 2000, 2001, 2006; Zhu et al., 2021).

In the SEM experimental observation, it is obvious that illite is the main component of sandstone interlayer clay minerals, and the other clay mineral components are relatively rare, indicating that the higher paleogeothermal temperature is conducive to the formation of illite in the process of basin evolution. Illite associated with I/S 

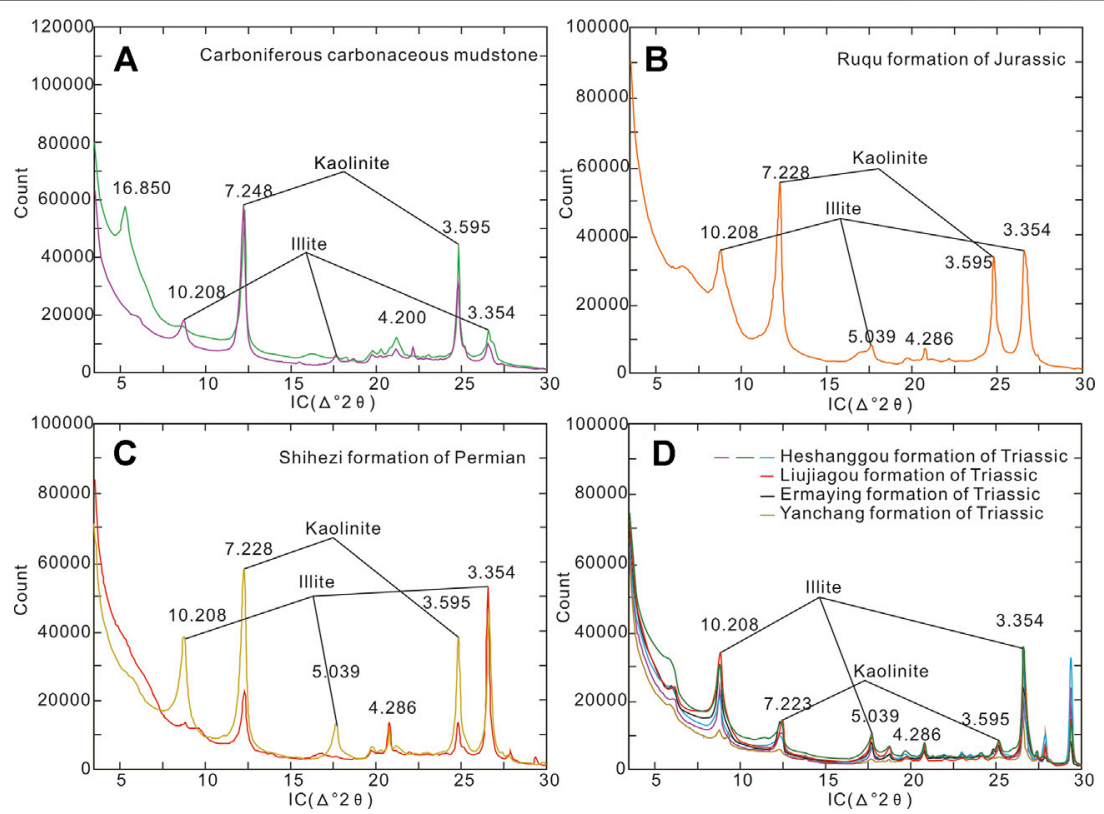

FIGURE 4 | X-ray diffraction of illite in central Qinshui Basin. (A) Carboniferous carbonaceous mudstone. (B) Ruqu formation of Jurassic sample. (C) Shihezi formation of Permian sample. (D) Triassic formation sample.
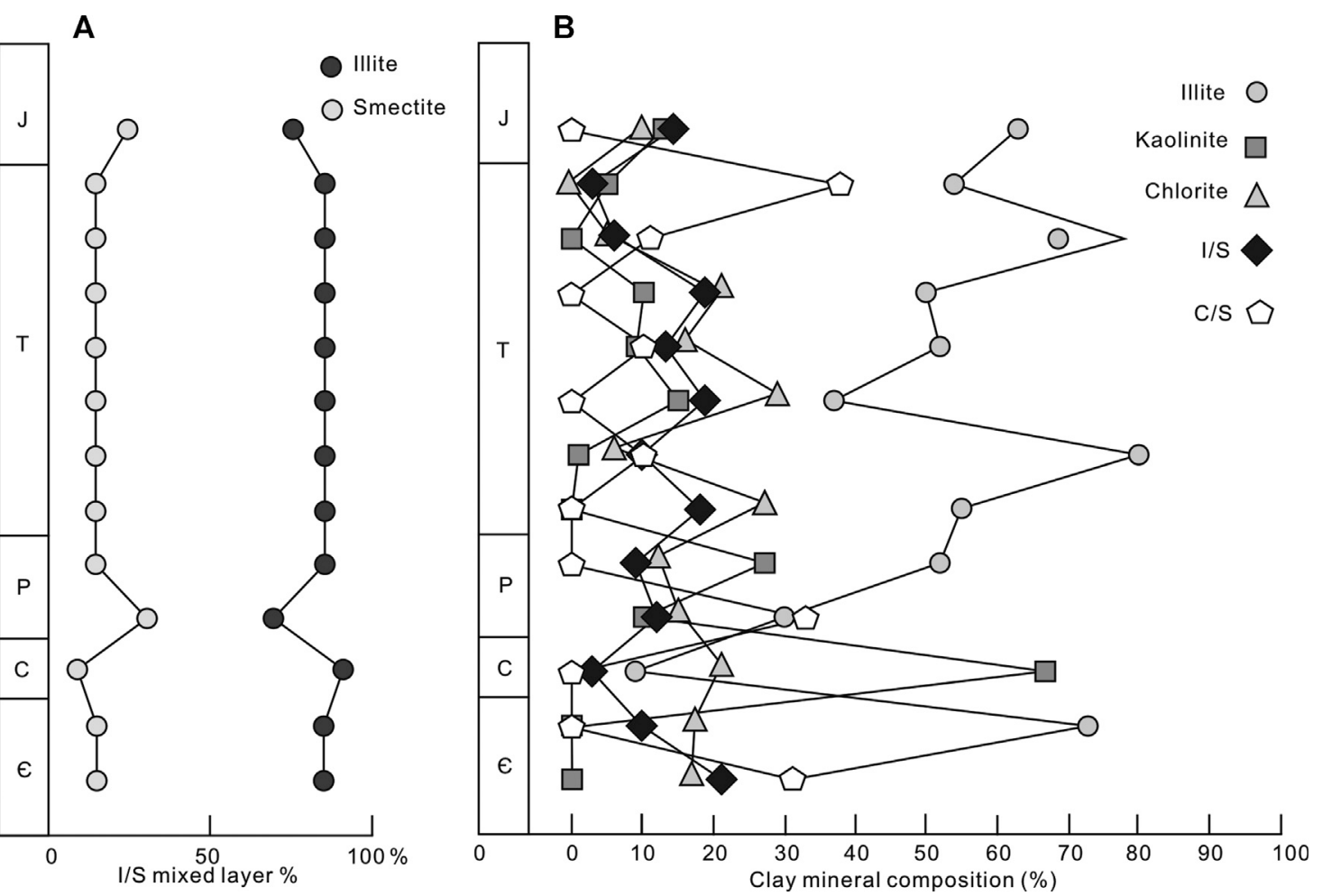

FIGURE 5 | Distribution of crystallinity and clay minerals map (A) Illite content and stratum change diagram in I/S layer (B) Clay mineral and stratum distribution diagram.

may be authigenic illite, but it may be affected by grinding flakes resulting in the formation of imperfect plates. However, it can be seen that many illite crystals growing alone have good crystal forms, showing rose and feather crystal forms (Figure 6I). Generally, illite with good crystal form represents the authigenic illite, but the crystalline morphology of terrigenous clastic illite is generally poor and is easy to be damaged in the process of long-distance transportation. 


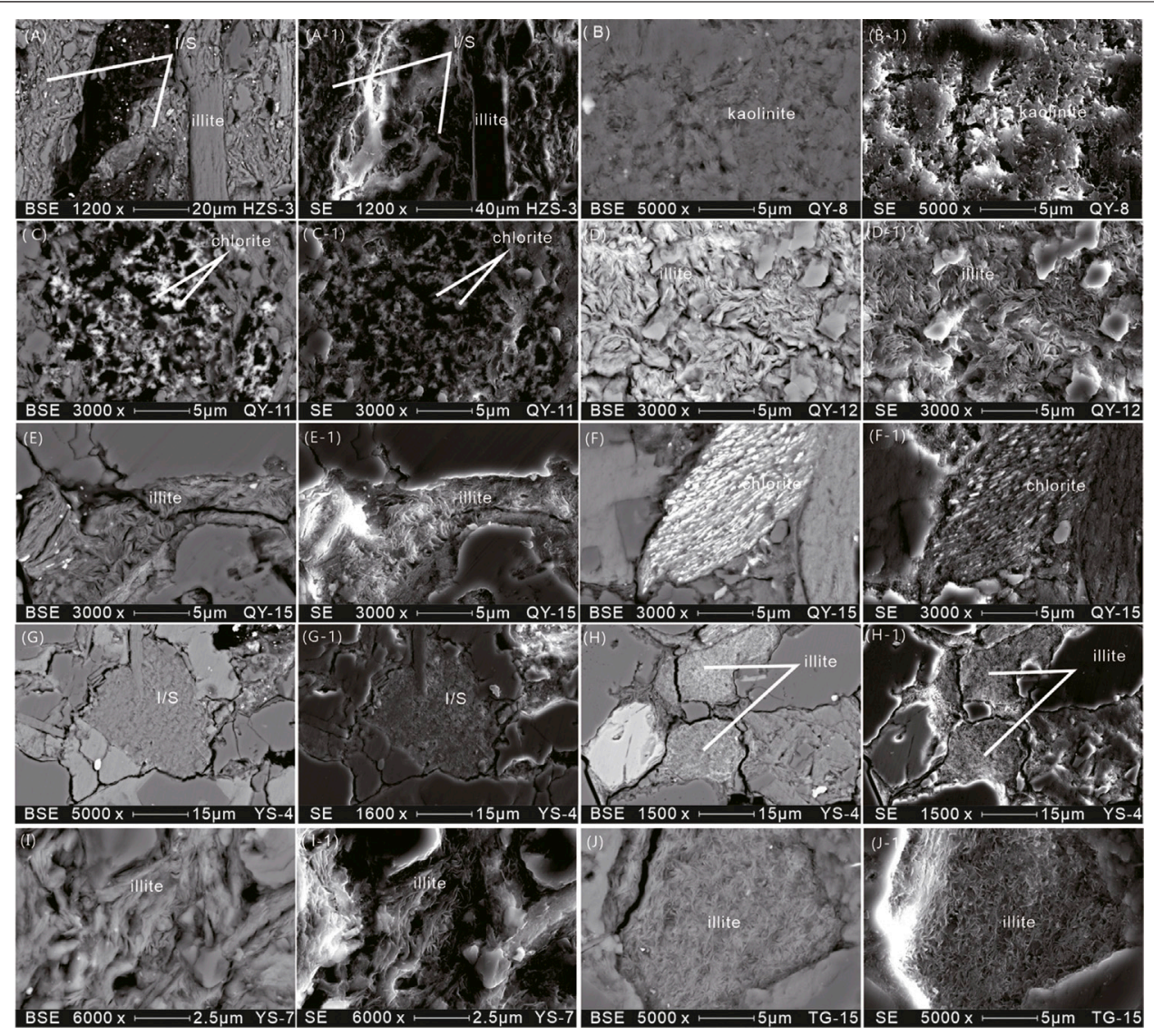

FIGURE 6 | The "(A)" represents BSE section photomicrographs and "(A-1)" represents SE section photomicrographs, which are the same structure, and so are other pictures. (A) and (A-1) illustrating textural features of cotton wadded I-S (R=3) and strip illite in Cambrian mudstone (HZS-3). (B) and (B-1) illustrating textural features of vermicular porous kaolinite in maroon iron clay rock of the Carboniferous Hutian section (QY-8). (C) and (C-1) illustrating textural features of blade chlorite in Grayish black mud shale of the upper Paleozoic Shihezi Formation (QY-11). (D) and (-1) illustrating textural features of feathery and filamentous illite in Grayish black silty mudstone of the upper Paleozoic Shihezi Formation (QY-12). (E) and (-1) illustrating textural features of feathery and bridged illite in the purple-red mudstone of Lower Triassic Heshanggou Formation of Mesozoic (QY-15). (F) and (-1) illustrating textural features of needle-shaped and laminated chlorite in the purple-red mudstone of Lower Triassic Heshanggou Formation of Mesozoic (QY-15). (G) and (-1) illustrating textural features of cotton wadded I/S (R = 3) in mudstone of the Lower Triassic Heshanggou Formation of Mesozoic (YS-4). (H) and (-1) illustrating textural features of ribbon-packed, strip-shaped illite in mudstone of the Lower Triassic Heshanggou Formation of Mesozoic (YS-4). (I) and (-1) illustrating textural features of roseate illite in purple mudstone of the Middle Triassic Ermaying Formation of Mesozoic (YS-7). (J) and (-1) illustrating textural features of filamentous and feathery illite in purple mudstone of the Upper Triassic Yanchang Formation of Mesozoic (TG-15).

\section{Paleotemperature Restoration}

\section{Paleotemperature Restored by Vitrinite Reflectance}

The vitrinite reflectance of the Qincan 1 well is between 1.0 and $2.5 \%$ at the range of 500-1,000 $\mathrm{m}$ depth (Supplementary Table S3). The evolution degree of organic matter belongs to high maturity or over-maturity, combined with low current geothermal gradient, indicating that the basin has experienced high paleotemperature.

Based on the strong correlation between vitrinite reflectance and maximum paleotemperature, the maximum paleotemperature that the stratum experienced can be calculated (Barker et al., 2016; Yang et al., 2017a, 2020). According to the relationship between the maximum paleotemperature and the burial depth, we can determine the paleo-gradient, the relationship between $\ln \left(R_{o}\right)$ and $\mathrm{T}_{\max } /{ }^{\circ} \mathrm{C}$ is calculated as follows:

$$
\ln (R o)=0.0096 T_{\max }-1.4
$$

According to this formula, the relationship between the maximum paleotemperature and depth of the Qincan 1 well in the central part of the Qinshui Basin can be obtained (Supplementary Table S3; Figure 7).

According to Vitrinite reflectance data from the Qincan 1 well, we calculated the maximum paleotemperature gradient to be $6.5^{\circ} \mathrm{C} /$ $100 \mathrm{~m}$, however, the current geothermal gradient of the Qincan 1 well is $2.4^{\circ} \mathrm{C} / 100 \mathrm{~m}$, which means the paleotemperature gradient is significantly higher than the current geothermal gradient (Figure 7).

\section{Paleotemperature Restored by Illite Crystallinity}

We tested the illite crystallinity of mudstone samples from Permian to Triassic, which we also calibrated with international standard samples.

According to Supplementary Table S1, we observed a correlation between the age of the stratum and the altitude; when altitude decreases and formation ages get older, the illite crystallinity of outcropping samples in the field gradually decreases, implying that the paleotemperature gradually increases. Therefore, there is a strong correlation between the 


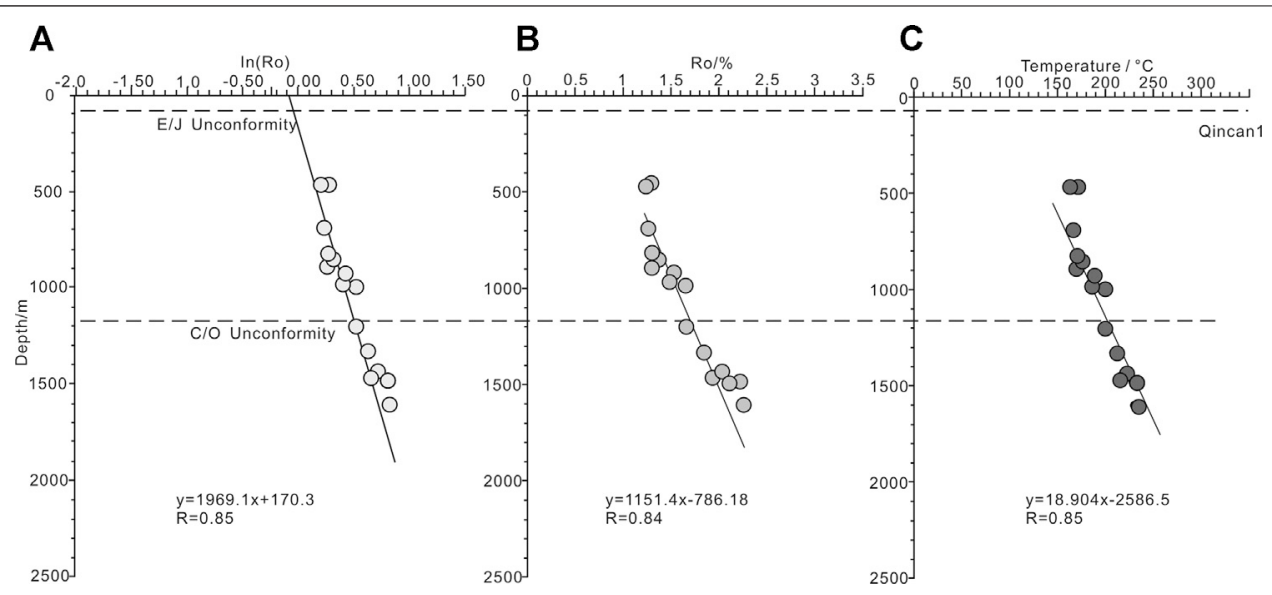

FIGURE 7 | Vitrinite reflectance $\left(R_{0}\right)$ and depth map. (A)The relationship between $I n\left(R_{0}\right)$ and depth of Qincan 1 . (B) The relationship between Ro and depth of Qincan 1. (C) Maximum palegeotemperature of Qincan 1 well in central basin reverted by Ro.

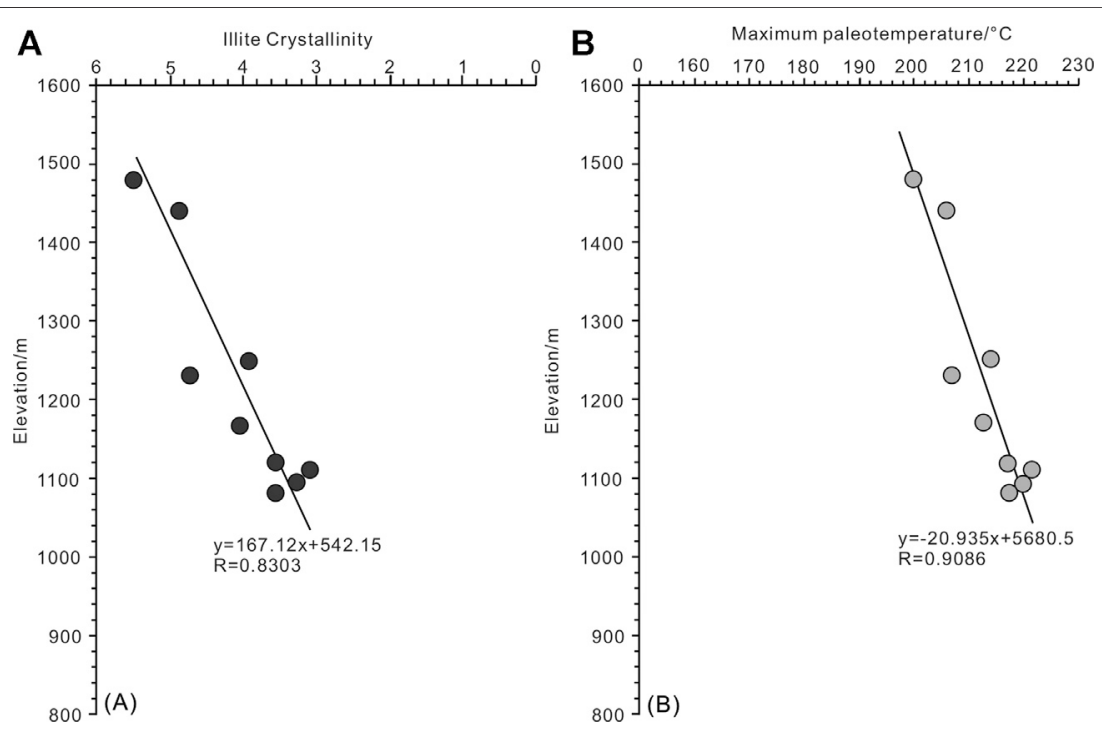

FIGURE 8 | Illite crystallinity, Illite crystallinity inversion of maximum paleotemperature and elevation map (A) Illite crystallinity and elevation map in central Qinshui Basin. (B) Maximum paleotemperature inverted by Illite crystallinity in central Qinshui Basin.

sampling altitude and the maximum paleotemperature calculated by illite crystallinity (Figure 8).

The characteristics of illite crystallinity of mudstone in the central Qinshui Basin decrease from top to bottom, indicating that the basin and surrounding orogenic belt were continuously uplifted and denuded to deeper and higher metamorphic degrees after the Late Triassic. For some of the samples, illite crystallinity is between 0.25 and $0.42^{\circ}$, it belongs to low-grade metamorphism, reflecting the characteristics of illite of denuded Precambrian metamorphic around the basin. Combined with the high content of illite in the I/S mixed layer (Figure 5A) and moderate contents of kaolinite in the clay minerals (Figure 5B), this indicated that the clay minerals in the mudstone were affected by a high-temperature geothermal field.
Illite/smectite (I/S) mixed-layer minerals are the most widely distributed mixed-layer clay minerals in sedimentary rocks. It is produced due to the mixing of the two terminal elements of illite and smectite in different proportions. Experimental studies have confirmed that when the temperature or depth increases, the proportion of the illite layer in the I/S layer gradually increases (Ramseyer and Boles, 1986). This is associated with the gradual transformation of the mixed layer from a disordered to an ordered structure. The degree of order of various types of I/S layer mineral structure and its existence temperature ranges are respectively (Harvey and Browne, 1991; M, 1993):

$\mathrm{R}=0$ type, $\mathrm{R}_{0} \mathrm{I} / \mathrm{S}$, illite content $<60 \%$, stable temperature $<140^{\circ} \mathrm{C} ; \mathrm{R}=1$ type, $\mathrm{R}_{1} \mathrm{I} / \mathrm{S}$, illite content $60-85 \%$, stable temperature $100-180^{\circ} \mathrm{C} ; \mathrm{R}=3$ type, $\mathrm{R}_{3} \mathrm{I} / \mathrm{S}$, illite content $>85 \%$, stable temperature $>190^{\circ} \mathrm{C}$; The relationship between 
the crystallinity of illite and its formation temperature has already been established in previous studies from Ji (2000). Our work relies on these results to calculate the formation temperature of authigenic illite. The relationship between the crystallinity of authigenic illite $\left(\mathrm{IC} /{ }^{\circ}\right)$ and its formation temperature $\left(\mathrm{T} /{ }^{\circ} \mathrm{C}\right)$ is as follows:

$$
T=384.98 e-0.6219 \times I C
$$

To use crystallinity of illite minerals (including I/S minerals), recovery paleotemperatures, and stratum denudation depths, we considered the distribution of outcrop strata and studied two sections, the paleo-geothermal temperature of illite crystallinity recovery is between 200 and $220^{\circ} \mathrm{C}$ (Supplementary Table S1); overall, the temperature increases with the age of the stratum, and decreases with the sample elevation.

\section{Erosion Thickness Restoration Erosion Thickness Restored by Vitrinite Reflectance} With the increase of burial temperature, the degree of the thermal evolution of organic matter gradually increases, and the value of vitrinite reflectance $\left(R_{o}\right)$ increases. However, the thermal evolution process of vitrinite reflectance is irreversible; in other words, when a formation is uplifted and cooled, the Vitrinite reflectance value will not decrease as the temperature decreases. Therefore, through a certain conversion relationship (Barker and Pawlewicz, 1986), it is possible to restore the highest ancient geothermal temperature reached in the geological period recorded by vitrinite reflectance. Based on the vitrinite reflectance distributed in the upper and lower structural layers of the unconformity, Dow (1977) used a different method to estimate the denudation thickness of a certain period for a formation. The application of the vitrinite reflectance difference method in the research fields of basin subsidence history, tectonic evolution history, or tectono-thermal evolution history, has shortcomings, as explained by several authors (Chen et al., 1999; Hu et al., 1999; Tong et al., 2005; Tong and Zhu, 2006), who made reasonable improvements, which we as describe below.

$\mathrm{Hu}$ et al. (1999) pointed out that the method proposed by Dow (1977) to directly estimate the uplift scale and denudation amount of strata by using the Vitrinite reflectance data above and below the unconformity surface lacks theoretical basis, and the results obtained by this method does not correspond to the represented denudation thickness but is equivalent to the loss amount of strata caused by normal fault dislocation. Chen et al. (1999) considered that the effect of reburial on the vitrinite reflectance distributed above and below the unconformity surface is different, and considered that in the early stage of reburial, the vitrinite reflectance in the upper part of the unconformity surface changes greatly, while that in the lower part of the unconformity surface it changes less. When the reburial process reaches a certain extent, the difference between the vitrinite reflectance above and below the unconformity surface will become smaller and smaller, even unable to be distinguished, which brings some difficulties to estimating the denudation thickness by using the alternate method by Dow (1977). Therefore, Chen et al. (1999) proposed a vitrinite reflectance method based on the Dow (1977) method to restore the denudation thickness. Based on the theory of Dow (1977), Chen et al. (1999), Tong et al. (2005), and Tong and Zhu. (2006) further developed the maximum paleotemperature method which links the denudation thickness and Vitrinite reflectance value. First, this new method has the advantage of being similar in the determination of the highest paleotemperature, and second, it has a simple calculation process. We reconstructed the denudation thickness by using the vitrinite reflectance distributed in the underlying stratum of the unconformity. Based on vitrinite reflectance, we also established a linear regression relationship between Vitrinite reflectance and the depth, and by extrapolating it to $\ln (0.2)=$ 1.61 , we obtained the approximate paleo-surface elevation. The elevation difference between the paleo-surface and unconformity is the denudation thickness of the formation. Through this method, we estimated the denudation thickness of Jurassic formation in the Qincan 1 well to be $\sim 3,269 \mathrm{~m}$ (Figure 9).

\section{Erosion Thickness Restored by Illite Crystallinity}

The principle of using paleogeotemperature and paleotemperature gradient to estimate the denudation thickness of the formation is similar to the calculation of the denudation thickness by vitrinite reflectance, both being based on the difference between paleo-surface and current surface. Additionally, we can use the diversity of the paleotemperature and the current temperature for a similar depth to reconstruct the denudation thickness (Figure 9). Firstly, we should calculate the paleo-gradient using both paleotemperature and depth data (Supplementary Table S1; Figure 9). Concerning heat balance basin (the paleo-gradient is similar to the current gradient), we use the difference between paleogeotemperature and the current temperature at denudation surface or stratum interface to calculate the denudation thickness by the relationship between geotemperature and depth (Dow, 1977). For our purposes, we should first apply heat balance correction for the heat imbalance basin, in other words, we should subtract the temperature drop caused by the nature of the basin, cooling from paleogeotemperature to the current geotemperature, and then calculate the ablation thickness based on geotemperature difference between paleogeotemperature and current geotemperature at the denudation surface (Dow, 1977). Here, the ablation thickness represents the height difference between ancient and present surfaces (Figure 9).

Such corrections, as described above, must be applied in the case of the Qinshui Basin, an imbalance basin, since the paleotemperature gradient is much higher than the present gradient. Therefore, we use the paleotemperature data (Supplementary Table S1) which was calculated by illite crystallinity from mudstone in the Zijinshan mountain section, and by extrapolation on the graph of temperature vs depth, we obtain the trend line of paleotemperature gradient (Figure 8). By comparing the current geotemperature gradient with heat balance correction, we calculate an erosion thickness of $\sim 3181 \mathrm{~m}$ (Figure 9). 

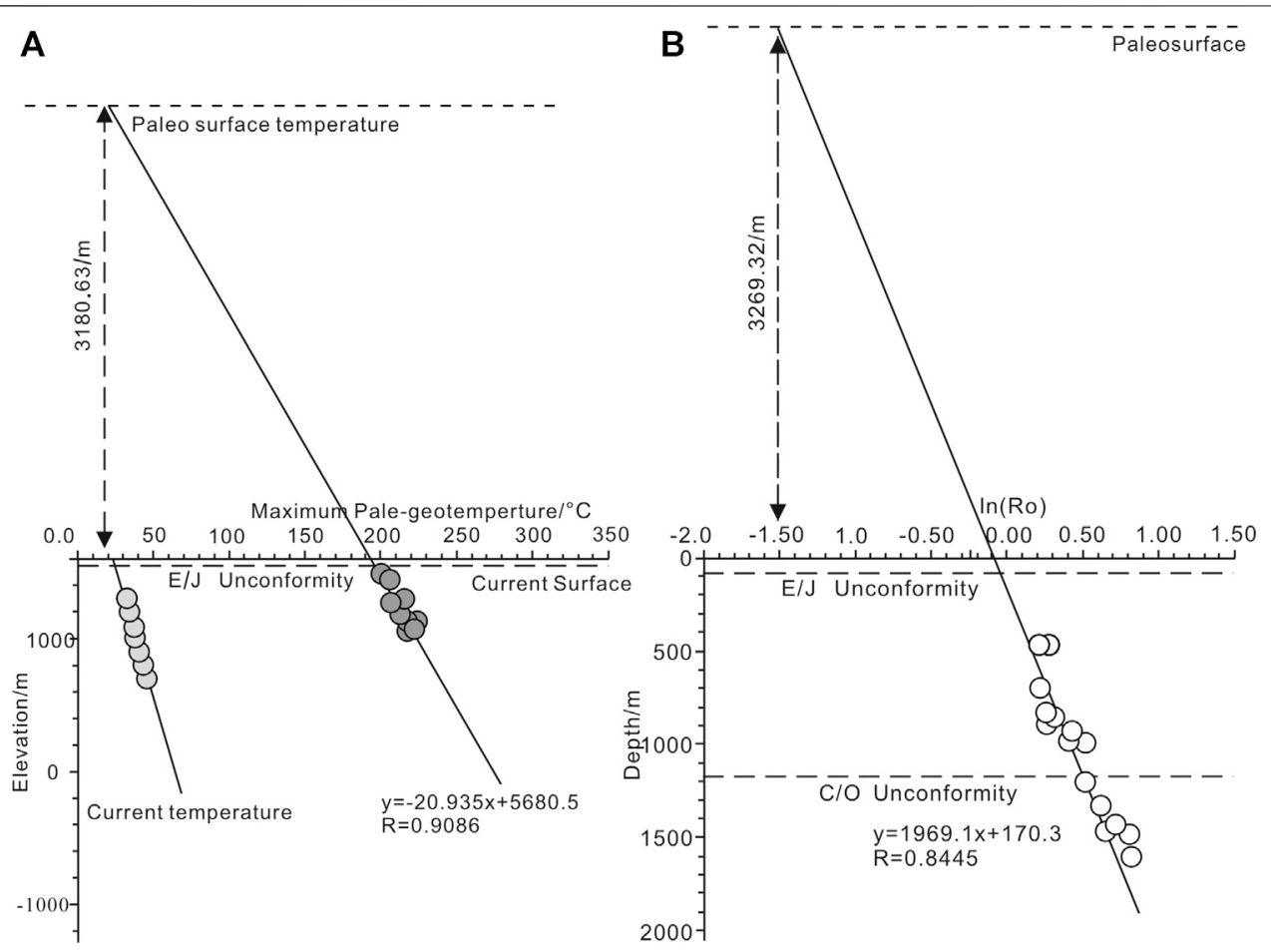

FIGURE 9 | Denudation thickness of central Qinshui Basin (A) Denudation thickness restored by illite crystallinity. (B) Denudation thickness of Qincan 1 well restored by $\ln \left(R_{o}\right)$.

\section{Burial History and Tectono-Thermal History Restoration}

Based on the reconstruction of the maximum paleotemperature of the basin, the tectono-thermal history of well Qincan 1 was simulated by the software Basin Mod 1D (Figure 10). The software includes several models, such as burial history, tectono-thermal history, hydrocarbon generation history, migration, and accumulation history. In this study, we mainly use the Basin Mod 1D module to simulate the burial history and tectono-thermal history of the Qinshui basin.

Firstly, the relationship between vitrinite reflectance and depth is used to calculate the denudation thickness since the Early Cretaceous thermal event (Figure 9), estimated at 3,269.32 m. Secondly, combined with geological parameters such as stratum stratification data of the Qincan 1 well and the geological background in the middle of Qinshui Basin, the burial history curve of the Qincan 1 well is established. According to the apatite fission-track (AFT) study results (Zhu et al., 2014), the AFT data (Zhu, 2013) reflect the uplift process since the Early Cretaceous. Finally, by adjusting the amount of strata denudation and geothermal gradient, the simulated Vitrinite reflectance should be consistent with the measured Vitrinite reflectance, and the accurate tectono-thermal history evolution path can be obtained.

From Figure 10, it appears clear that the change of geothermal flow can be divided into two stages. The first stage is characterized by a large geothermal flow of $\sim 68 \mathrm{Mw} / \mathrm{m}^{2}$, in the Early Carboniferous, and slowly decreasing to $60 \mathrm{~mW} / \mathrm{m}^{2}$ in the Late Triassic; the second stage corresponds to a geothermal flow gradually rising, reaching a peak value of $84.8 \mathrm{~mW} / \mathrm{m}^{2}$ in the Early Cretaceous, and then decreasing to $61.69 \mathrm{~mW} / \mathrm{m}^{2}$ at the present-day.

According to simulations, the evolution of the paleogeotemperature gradient is also divided into two stages. The first stage, from the Early Carboniferous to the Late Triassic, is relatively stable at $2.9^{\circ} \mathrm{C} / 100 \mathrm{~m}$, and a second stage, taking place after the Late Triassic, where the paleogeotemperature gradient increased to a maximum value of $6.51^{\circ} \mathrm{C} / 100 \mathrm{~m}$ during the Early Cretaceous (Figure 10). According to the burial history (Figure 10), the basin reached its maximum depth at the EarlyMiddle Cretaceous, and gradually uplifted from the Middle-Late Cretaceous. The relationship between the simulated vitrinite reflectance curve and the measured vitrinite reflectance curve fit well, indicating that the tectono-thermal history recovery is reliable.

\section{DISCUSSION}

\section{Separation of Illite}

If the separation of illite is not so pure, the determined value of the crystallinity of illite may include some bias due to the presence of detrital illite. Detrital illite refers here to terrigenous illite detritus deposited concomitantly with sediments, mainly from metamorphic illite originating from the study area. Consequently, the paleo-geotemperature reflected by the crystallinity of illite may not reflect the paleo-geotemperature of the source strata, but the provenance. Therefore, the separation and 


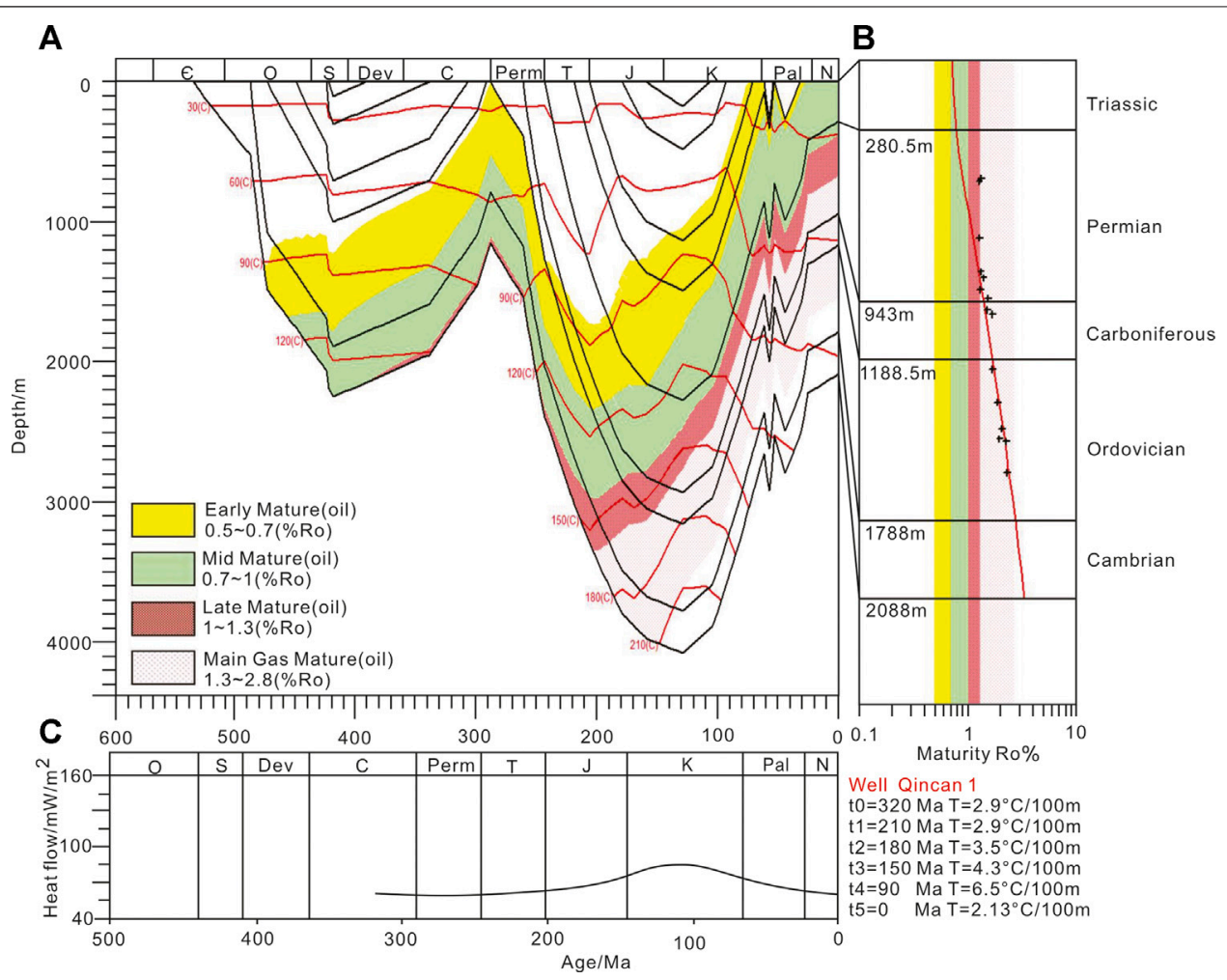

FIGURE 10 | Recovery of burial history and tectono-thermal history of Qincan 1 well in central Qinshui Basin. (A) Burial history and tectono-thermal history of Qincan 1 well. (B) Fitting relationship between measured Ro and simulated Ro. (C) Geothermal flow evolution in different periods of Qincan 1 well.

purification of authigenic illite is an important step to avoid the presence of detrital illite. To determine the crystallinity of authigenic illite, we must separate the authigenic illite from sandstone, mudstone, fault gouge, and other types of rock samples first, then remove the non-authigenic illite components from the rock samples and finally extract the authigenic illite.

As explained, the separation of authigenic illite will have a direct influence on the quality of the testing results; separation and purification of illite are essential to maximize the complete removal of detrital K-bearing minerals such as detrital K-feldspar and detrital illite. Moreover, the authigenic illite should also be enriched to the greatest extent, whereas the content of kaolinite, chlorite, smectite, and other non-authigenic illite components should be reduced to the greatest extent. Judging from the current situation, the only effective way to achieve this goal is to extract more fine-grained clay components.

The separation of illite is quite challenging for two reasons. Firstly, the separation of authigenic illite requires a fine particle size. Conventional clay separation generally requires the extraction of $<2 \mu \mathrm{m}$ components, while the separation of authigenic illite requires at least particle size of $<0.3 \mu \mathrm{m}$; Secondly, the separation of authigenic illite requires successive separation steps to extract different continuous fractions simultaneously, e.g., $1-0.5 \mu \mathrm{m}$, $0.5-0.3 \mu \mathrm{m}, 0.3-0.15 \mu \mathrm{m}$, and $<0.15 \mu \mathrm{m}$. The separation and purification of illite are generally limited by instruments and equipment, and the separation was carried out to fraction sizes of $0.5 \mu \mathrm{m}$. Therefore, the clay minerals finally separated and purified may contain some detrital illite, chlorite, kaolinite, and other clay minerals, which might affect the test results. According to the XRD patterns (Figure 6 and Figure 4), we can observe diffraction patterns characteristics of chlorite and kaolinite, which therefore indicate that the separation of early authigenic illite is not completely pure. Consequently, the calculated illite crystallinity might include detrital illite crystallinity, which might have an impact on the paleotemperature inversion calculation. But through the SEM (Supplementary Material, Figure 6), Most of the clay minerals in the sandstone interlayer are illite with a good crystal shape (Figure 6), and some illites are associated with I/S (Figure 6A), indicating that there are many authigenic illites to some extent.

\section{Tectono-Thermal Event Time and Coalbed Methane Accumulation Period}

According to the calculation results of the illite crystallinity and the vitrinite reflectance of well Qincan 1, a strong tectono-thermal event occurred in the basin. As a result, the maximum ancient geothermal gradient is $6.5^{\circ} \mathrm{C} / 100 \mathrm{~m}$, which is larger than the current geothermal gradient of $2.4^{\circ} \mathrm{C} / 100 \mathrm{~m}$, and the maximum paleo-geotemperature was around $180-190^{\circ} \mathrm{C}$ as recorded at the Carboniferous strata.

Previous studies have attempted to determine the occurrence time of tectono-thermal events in Qinshui Basin; the fission-track age of apatite, for example, is estimated at $\sim 20-40 \mathrm{Ma}$, and the 


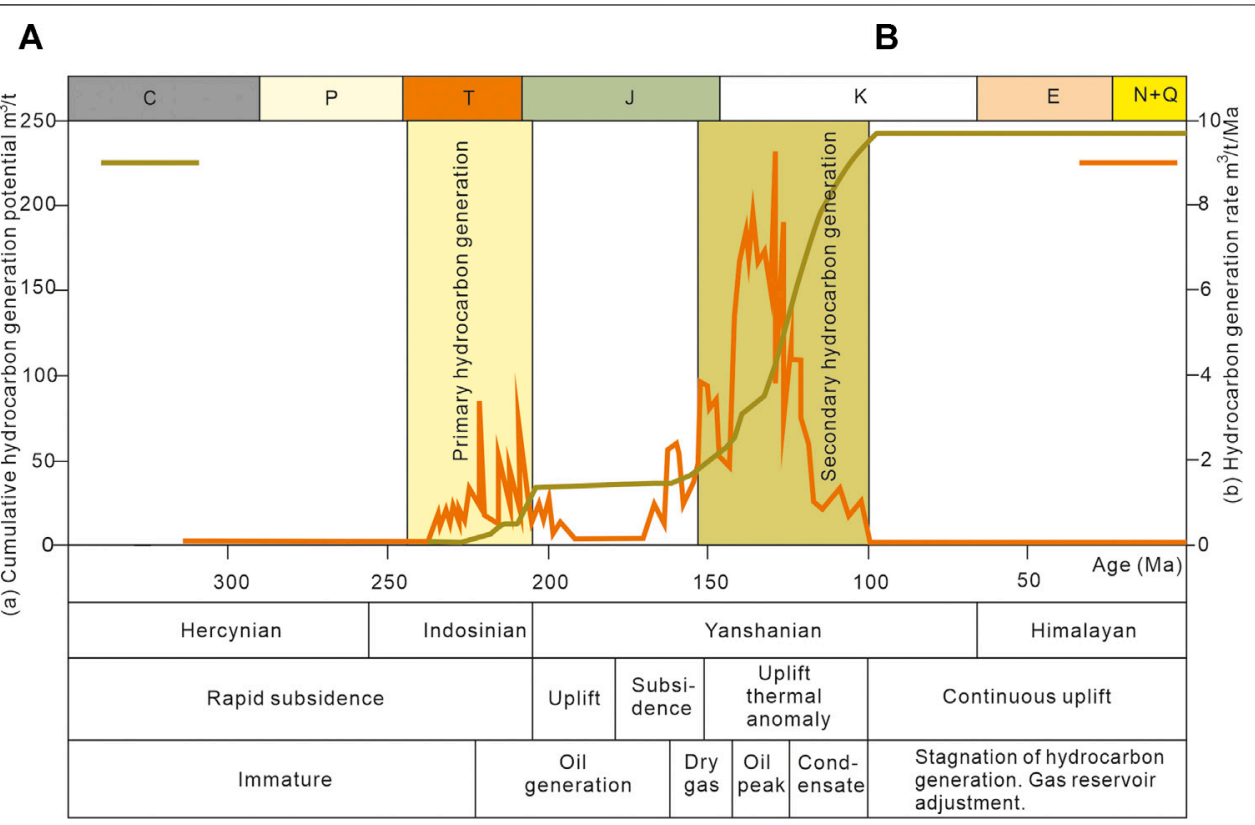

FIGURE 11 | Evolution of hydrocarbon generation potential and rate of source rocks in Qinshui Basin, modified from Hou, (2020).

zircon fission-track age is $\sim 100-150 \mathrm{Ma}$ (Ren et al., 2005; Zhu et al., 2014). If the fission-track age of zircon happened to be smaller than the age of the formation, it would indicate that the formation temperature was once greater than $250{ }^{\circ} \mathrm{C}$ and that the zircon has undergone annealing (Hurford, 1986; Fitzgerald and Gleadow, 1988; Yan et al., 2010; Malusà and Fitzgerald, 2019). Secondly, the isotope age determination results of the igneous rocks around the Qinshui Basin indicate that the time of magma intrusion and eruption is between the Late Jurassic and Early Cretaceous. For example, the Taershan-Erfengshan alkaline complex, which is in the southwest of the Qinshui Basin, has an Ar-Ar age of about $124 \pm 0.3 \mathrm{Ma}$. In addition, the $\mathrm{U}-\mathrm{Pb}$ age of the Wanrong-Gufeng Mountain in the southern Qinshui Basin ranges between $127 \pm 1 \mathrm{Ma} 140.5 \pm 5.3 \mathrm{Ma}$ (Yan et al., 1988; Shanxi, 1989; Wu et al., 1996, 2008; Ying et al., 2011; Si, 2015; Huo, 2016; Yang, 2016; Chang et al., 2017; Yang et al., 2017). It shows that the tectono-thermal events mainly occurred in the Late Jurassic to the Early Cretaceous period (More details in Supplementary Table S4 and Supplementary Figure S1).

Among the geological factors, thermal field, tectonic stress field, hydrodynamic field, and formation conditions have an important influence on the formation of coalbed methane (Wu et al., 2014). The coal deposits in the Qinshui Basin began to form in the Late Carboniferous and gradually ceased when the delta deposits were formed in the early Permian (Sun et al., 2005; Ma et al., 2016; Chen et al., 2019; Yu et al., 2020a). The subsidence of the basin lasted until the Late Triassic when the temperature of the coal seam reached $135^{\circ} \mathrm{C}$ (the burial depth was up to $4 \mathrm{~km}$ ). Influenced by the increase of temperature, the first stage of methane generation began, and the vitrinite reflectance maturity of the coal seam reached a medium level $\left(R_{o} \approx 1.2 \%\right)$ (Zeng et al., 1999; Cai et al., 2011). Then, the subsequent Indosinian orogenic movement caused the uplift and inversion of the basin during the Early Jurassic, and it remained in a state of slow deposition until the Late Jurassic (Zeng et al., 1999; Ma et al., 2016). At the same time, the exposed rocks around the Qinshui Basin, which include Taershan, Huyanshan, Zijinshan, Erfengshan, Gufengshan, etc, started to form (Yan et al., 1988; Shanxi, 1989; Wu et al., 1996, 2008; Ying et al., 2011; Si, 2015; Huo, 2016; Yang, 2016; Chang et al., 2017; Yang et al., 2017). It can be seen that there was a tectono-thermal event represented by intense magmatic activity in the Late Jurassic to Early Cretaceous, which is generally considered to be closely related to the secondary gas peak of coal seams in the basin at the same time (Figure 11) (Zeng et al., 1999; Xu et al., 2004; Jiang et al., 2005; Ren et al., 2005; Sun et al., 2005; Duan et al., 2011; Chen et al., 2019, 2019; Yu et al., 2020a; Gao et al., 2021).

From Late Jurassic to Early Cretaceous, magmatic thermal events caused rapid temperature increase of coal measures. A large amount of hydrocarbon was generated by coal measures, with coal rock as the main source of hydrocarbon generation. The rapid increase of gas led to hydrocarbon generation pressurization in the coal body (Ju et al., 2018); furthermore, the increase of temperature led to the expansion of gas to form abnormal high pressure (Figure 11).

\section{Response of Thermal Events in Qinshui Basin to Destruction of NCC}

The tectono-thermal event in Qinshui Basin between the Late Jurassic to Early Cretaceous was associated with the large-scale magmatic eruption and the formation of the Ultra-HighPressure metamorphic belt (Yan et al., 1988; Shanxi, 1989; Wu et al., 1996; Zhang, 1997, 2002; Wu et al., 2008; Ying et al., 2011; Chen and Ding, 2012; Si, 2015; Huo, 2016; Yang, 
2016; Chang et al., 2017; Yang et al., 2017; Yu et al., 2020a). Combined with the estimation of the maximum paleotemperature and paleotemperature gradient of illite crystallinity and vitrinite reflectance, the deep mantle of the basin was active during the Late Jurassic-Early Cretaceous with the lithosphere thinned and led to the formation of a high geothermal background value of mantle upwelling, which was the main reason for the tectono-thermal event and uplift denudation event of the basin in this period.

Previous studies have shown that the thickness of the thermal lithosphere of the present orogenic belt in the central part of the NCC is about 76-90 km (He et al., 2001; Wang et al., 2001; Zhang et al., 2006; Zhang, 2012). Based on their data, these authors estimated that the thickness of the thermal lithosphere of the Qinshui Basin in the Early Cretaceous was about $50-60 \mathrm{~km}$, indicating that the lithosphere of the basin was thinned during the Early Cretaceous. At the same time, previous studies suggest that the NCC experienced strong lithospheric thinning and lithospheric mantle property transformation during the Mesozoic (Menzies et al., 1993; Griffin et al., 1998; Xu, 2001; Wu et al., 2008), accompanied by strong magmatism (F. Wu et al., 2005a; F.-Y. Wu et al., 2005b; Yang et al., 2008). Combined with the magmatism around the Qinshui Basin, we suggest that the lithospheric thinning in the Qinshui Basin is controlled by the thinning and destruction of the NCC.

Previous investigations have been conducted on the destruction of the NCC (Zhu et al., 2012, 2017; Yang et al., 2021b). According to Zhu et al. (2017), at $165 \mathrm{Ma}$, from the beginning of the Middle Jurassic Yanshanian movement episode A, the West Pacific plate subducted to the East Asian continental margin with a high speed and low angle, the tectonic environment in Qinshui Basin, therefore, corresponds to a compression environment, and angular unconformity events were generally developed. Starting from the Late Jurassic at $155 \mathrm{Ma}$, the western Pacific plate subducted from a low angle to a high angle subduction toward the edge of the East Asian continent (Zheng et al., 2018). With the rotation and retreat of the subducted plate, the corresponding tectonic environment of the Qinshui Basin became extensional, and magmatic activity began to appear; during this period, the Taihang Mountains began to uplift, and the eastern part of the Qinshui Basin as the western wing of the Taihang Mountains began to fold and uplift (Zhu, 2013). Accompanied by strong magmatism, the Late Paleozoic coalmeasure strata experienced a high-temperature heating process. The regional tectonic stress field of the basin during the Middle-Late Jurassic is consistent with that of the whole of eastern China. The NNE trending folds are the most developed in the basin, covering the whole area on a large scale, reflecting the horizontal compressive stress field in the direction of NWW-SEE in the Yanshanian period. Under the action of this stress field, a wide and gently deformed syncline, Qinshui Basin, is formed (Zhu et al., 2015). At $140 \mathrm{Ma}$, the Yanshanian movement episode B began in the early Cretaceous, and the subduction angle of the Western Pacific plate to the East Asian continental margin began to decrease again. The tectonic environment corresponding to the Qinshui Basin was compressional, and crustal shortening, folding and stratigraphic angular unconformity events were widely developed (Zheng et al., 2018). From $125 \mathrm{Ma}$ in the Early Cretaceous, the subduction angle of the Western Pacific plate to the East Asian continental margin changed to a high angle again, and the rate of subduction, rotation, and retreat reached the maximum, and finally left a retentive body in the mantle transition zone (Zhu et al., 2015). The corresponding area of Qinshui Basin, which was subjected to compression, thrust, and folds uplifting, began to develop structural inversion and normal faults. Since the late Cretaceous, the young and buoyant paleo Western Pacific plate gradually entered the subduction zone, and magmatic activity in the corresponding area of the Qinshui Basin gradually ceased, and the extensional tectonic activity was much weaker than that of the early Cretaceous (Shanxi, 1989). Throughout the Cretaceous period, there was a major structural system transition in eastern China, that is, the early continental collision and compression thrust structures were transformed into extensional structures, and the eastern NCC and Ordos basin became active with the lithosphere thinned (Ren et al., 2002; Chen and Ding, 2012; Yu et al., 2020b).

The Qinshui Basin is a transitional zone between rift basins in the east of the NCC and the Ordos Basin in the West, the thinning of the lithosphere and crustal extension also affected this area, forming a small amount of magmatic activity. The basin was subjected to weak NW-SE extensional tectonism and formed a series of small to normal faults based on the Yanshanian conjugate joints. Previous studies have shown that the deep cause of the early Cretaceous tectono-thermal events and the uplift and denudation events in the Qinshui Basin is mainly due to the subduction of the western Pacific plate into the deep part of the NCC, and the current low geothermal gradient in the Qinshui Basin is also affected by the withdrawal of the West Pacific Plate. Combined with the results of previous studies (Ren et al., 2020), our work suggests that the Qinshui Basin experienced a tectonothermal event during the Late Jurassic to Early Cretaceous which is in response to deep lithospheric thinning of the NCC.

\section{CONCLUSION}

Paleotemperature and denudation restoration by vitrinite reflectance and illite crystallinity shed new light on the tectono-thermal history and mechanisms for the evolution of the Qinshui Basin of the NCC, which also expounded the generation mechanism of coalbed methane and its response to the destruction of the NCC from the tectono-thermal history perspective. The Qinshui basin experienced a tectono-thermal event during the Late Jurassic-Early Cretaceous. The deep reason for this thermal event may be that relate to the subduction of the Western Pacific Plate to the East Asian Continent resulting in the upwelling of deep asthenosphere material and the thinning of lithosphere thickness in the Qingshui area. During the Late Jurassic-Early Cretaceous, the maximum pale-geotemoerature and the highest pale-geotemperature gradient are $200^{\circ} \mathrm{C}$, and 
$6.5^{\circ} \mathrm{C} / 100 \mathrm{~m}$, respectively, which is the main control on the scale of hydrocarbon generation.

\section{DATA AVAILABILITY STATEMENT}

The original contributions presented in the study are included in the article/Supplementary Material, further inquiries can be directed to the corresponding authors.

\section{AUTHOR CONTRIBUTIONS}

RL: Conceptualization, Methodology, Software, Experiment, Writing-original draft, Writing_review and editing. ZR: Modeling, Supervision, Funding acquisition. PY: Supervision, Conceptualization, Writing - original draft, review and editing. $\mathrm{HH}$ : Supervision, Funding acquisition. TS: Writing-review and editing. WG: Writing-original draft, Writing-editing. WL: Software, Experiment.

\section{REFERENCES}

Barker, C. E., and Pawlewicz, M. J. (1986). “The Correlation of Vitrinite Reflectance with Maximum Temperature in Humic Organic Matter," in In Paleogeothermics: Evaluation of Geothermal Conditions In the Geological Past Lecture Notes in Earth Sciences. Editors G. Buntebarth and L. Stegena (Berlin, Heidelberg: Springer), 79-93. doi:10.1007/BFb0012103

Barker, M. K., Mazarico, E., Neumann, G. A., Zuber, M. T., Haruyama, J., and Smith, D. E. (2016). A New Lunar Digital Elevation Model from the Lunar Orbiter Laser Altimeter and SELENE Terrain Camera. Icarus 273, 346-355. doi:10.1016/j.icarus.2015.07.039

Cai, Y., Liu, D., Yao, Y., Li, J., and Qiu, Y. (2011). Geological Controls on Prediction of Coalbed Methane of No. 3 Coal Seam in Southern Qinshui Basin, North China. Int. J. Coal Geology. 88, 101-112. doi:10.1016/j.coal.2011.08.009

Chang, L., Wang, C., and Ding, Z. (2011). Upper Mantle Anisotropy in the Ordos Block and its Margins. Sci. China Earth Sci. 54, 888-900. doi:10.1007/s11430010-4137-2

Chang, Z., Yang, H., and Zhou, A. (2017). LA-1CP-MS Zircon L-Pb Geochronology of the luyanshan Alkaline Intrusive Complex in the Luliang Mountain of North China Craton and its Geological Significance. Geol. Bull. China 36, 372-380. doi:10.1016/j.dib.2018.05.013

Chen, B., Stuart, F. M., Xu, S., Györe, D., and Liu, C. (2019). Evolution of Coal-Bed Methane in Southeast Qinshui Basin, China: Insights from Stable and noble Gas Isotopes. Chem. Geology. 529, 119298. doi:10.1016/j.chemgeo.2019.119298

Chen, G., and Ding, C. (2012). Analysis on the thermal History and Uplift Process of Zijinshan Intrusive Complex in the Eastern Ordos basin. Chin. J. Geophys. 55, 3731-3741. doi:10.6038/j.issn.0001-5733.2012.11.020

Chen, L. (2009). Lithospheric Structure Variations between the Eastern and central North China Craton from S- and P-Receiver Function Migration. Phys. Earth Planet. Interiors 173, 216-227. doi:10.1016/j.pepi.2008.11.011

Chen, S., Tang, D., Tao, S., Xu, H., Li, S., Zhao, J., et al. (2018). Characteristics of InSitu Stress Distribution and its Significance on the Coalbed Methane (CBM) Development in Fanzhuang-Zhengzhuang Block, Southern Qinshui Basin, China. J. Pet. Sci. Eng. 161, 108-120. doi:10.1016/j.petrol.2017.11.042

Chen, Z., Liu, G., and Hao, S. (1999). A Corrected Method of Using Vitrinite Reflectance Data to Estimate the Thickness of Sediment Removed at an Unconformity. Acta Sedimentologica Sinica 17, 141-144.

Dow, W. G. (1977). Kerogen Studies and Geological Interpretations. J. Geochemical Exploration 7, 79-99. doi:10.1016/0375-6742(77)90078-4

Duan, Y., Zhang, X., Sun, T., Wu, B., He, J., and Xu, L. (2011). Carbon and Hydrogen Isotopic Compositions and Their Evolutions of Gases Generated by

\section{FUNDING}

This work was supported by the National Natural Science Foundation of China (Grant Nos. 41630312, 41688103, 42102164).

\section{ACKNOWLEDGMENTS}

We sincerely thank Topic Science Editor Kai-jun Zhang for kind editorial handling and constructive work. We also thank two reviewers for their constructive and thoughtful comments, which significantly improved the manuscript. The authors are grateful to PetroChina Huabei Oilfield Company for supporting this study.

\section{SUPPLEMENTARY MATERIAL}

The Supplementary Material for this article can be found online at: https://www.frontiersin.org/articles/10.3389/feart.2021.765497/ full\#supplementary-material

Herbaceous Swamp Peat at Different thermal Maturity Stages. Chin. Sci. Bull. 56, 1383-1389. doi:10.1007/s11434-011-4356-8

Fitzgerald, P. G., and Gleadow, A. J. W. (1988). Fission-track Geochronology, Tectonics and Structure of the Transantarctic Mountains in Northern Victoria Land, Antarctica. Chem. Geology. Isotope Geosci. section 73, 169-198. doi:10.1016/0168-9622(88)90014-0

Gao, H.-T., Zhu, Y.-M., Shang, F.-H., and Chen, C.-Y. (2021). Study on the Shale Gas Reservoir-Forming Characteristics of the Taiyuan Formation in the Eastern Qinshui Basin, China. j nanosci nanotechnol 21, 72-84. doi:10.1166/ jnn.2021.18465

Gao, Z., Fan, Y., Xuan, Q., and Zheng, G. (2020). A Review of Shale Pore Structure Evolution Characteristics with Increasing thermal Maturities. Adv. Geo-energy Res. 4, 247-259. doi:10.46690/ager.2020.03.03

Griffin, W. L., Andi, Z., O’Reilly, S. Y., and Ryan, C. G. (1998). "Phanerozoic Evolution of the Lithosphere beneath the Sino-Korean Craton," in "Phanerozoic Evolution of the Lithosphere beneath the Sino-Korean Craton," in Geodynamics Series. Editors M. F. J. Flower, S. Chung, C. Lo, and T. Lee (Washington, D. C.: American Geophysical Union), 107-126. doi:10.1029/GD027p0107

Harvey, C. C., and Browne, P. R. L. (1991). Mixed-lay Er clay Geothermometry in the Wairakei Geothermal Field. 39, 614-621.doi:10.1346/ccmn.1991.0390607

$\mathrm{He}, \mathrm{L}$., Hu, S., and Wang, J. (2001). Characteristics of thermal Structure of Rock and Lithosphere in the Land Area of eastern China. Prog. Nat. Sci. 11.

He, L. (2015). Thermal Regime of the North China Craton: Implications for Craton Destruction. Earth-Science Rev. 140, 14-26. doi:10.1016/j.earscirev.2014.10.011

$\mathrm{Hu}, \mathrm{S}$., Wang, J., and Zhang, R. (1999). Using Vitrinite Reflectance Data to Estimate the Thickness of Stratum Denudation. Pet. exploration Dev. 26, 42-45+6.

Huo, T. (2016). Petrogenesis of Early Cretaceous Alkaline Intrusive Rocks in central North China Block: Constraints of Chronology and Sr-Nd-Hf Isotopes. Lithos 380-381, 105887. doi:10.1016/j.lithos.2020.105887

Hurford, A. J. (1986). Cooling and Uplift Patterns in the Lepontine Alps South Central Switzerland and an Age of Vertical Movement on the Insubric Fault Line. Contrib. Mineral. Petrol. 92, 413-427. doi:10.1007/BF00374424

Ji, J. (2000). Relationship between Illite Crystallinity and Temperature in Active Geothermal Systems of New Zealand. Clays and Clay Minerals 48, 139-144. doi:10.1346/ccmn.2000.0480117

Jiang, B., Qin, Y., Ju, Y., and Wang, J. (2005). Research on Tectonic Stress Field of Generate. J. China Univ. Mining \&Technology 34, 564-569.

Ju, Y., Sun, Y., Tan, J., Bu, H., Han, K., Li, X., et al. (2018). The Composition, Pore Structure Characterization and Deformation Mechanism of Coal-Bearing Shales from Tectonically Altered Coalfields in Eastern China. Fuel 234, 626-642. doi:10.1016/j.fuel.2018.06.116 
Kisch, H. J. (1990). Calibration of the Anchizone: a Critical Comparison of Illite "Crystallinity" Scales Used for Definition. J.metamorphic Geol. doi:10.1111/ j.1525-1314.1990.tb00455.x

Kisch, H. J. (1987). "Correlation between Indicators of Very Low Grade Metamorphism," in In Low Temperature Metamorphism. Editor M. Frey (Glasgow: Blackie.), 227-300.

Li, R., Wang, S., Lyu, S., Xiao, Y., Su, D., and Wang, J. (2018a). Dynamic Behaviours of Reservoir Pressure during Coalbed Methane Production in the Southern Qinshui Basin, North China. Eng. Geology. 238, 76-85. doi:10.1016/ j.enggeo.2018.03.002

Li, S., Lai, X., Liu, B., Wang, Z., He, J., and Sun, Y. (2011). Differences in Lithospheric Structures between Two Sides of Taihang Mountain Obtained from the Zhucheng-Yichuan Deep Seismic Sounding Profile. Sci. China Earth Sci. 54, 871-880. doi:10.1007/s11430-011-4191-4

Li, S., Tang, D., Xu, H., and Yang, Z. (2012a). Advanced Characterization of Physical Properties of Coals with Different Coal Structures by Nuclear Magnetic Resonance and X-ray Computed Tomography. Comput. Geosciences 48, 220-227. doi:10.1016/j.cageo.2012.01.004

Li, S., Zhao, G., Dai, L., Liu, X., Zhou, L., Santosh, M., et al. (2012b). Mesozoic Basins in Eastern China and Their Bearing on the Deconstruction of the North China Craton. J. Asian Earth Sci. 47, 64-79. doi:10.1016/j.jseaes.2011.06.008

Li, Z., Liu, D., Ranjith, P. G., Cai, Y., and Wang, Y. (2018b). Geological Controls on Variable Gas Concentrations: A Case Study of the Northern Gujiao Block, Northwestern Qinshui Basin, China. Mar. Pet. Geology. 92, 582-596. doi:10.1016/j.marpetgeo.2017.11.022

Ling, Y., Chen, L., Wei, Z., Jiang, M., and Wang, X. (2017). Crustal S-Velocity Structure and Radial Anisotropy beneath the Southern Part of central and Western North China Craton and the Adjacent Qilian Orogenic Belt from Ambient Noise Tomography. Sci. China Earth Sci. 60, 1752-1768. doi:10.1007/ s11430-017-9092-8

Liu, R. (2020). Meso-Cenozoic thermal Regime and Lithospheric Thinning in the Qin Shui Basin, Central North China Craton. Available at: https://kns.cnki.net/ $\mathrm{kcms} /$ detail/detail.asp $x$ ?dbcode $=$ CMFD\&dbname $=$ CMFD202101\&filename $=$ 1020314237.nh\&uniplatform $=$ NZKPT\&v=sLWw8HfJafeHh68xohfyB3rXgv Sc3Z1v0uHTFqt5\%25mmd2FsPSCIx6r\%25mmd2Bs2wBFnftthw4VC (Accessed September 23, 2021).

Ma, X., Song, Y., Liu, S., Jiang, L., and Hong, F. (2016). Experimental Study on History of Methane Adsorption Capacity of Carboniferous-Permian Coal in Ordos Basin, China. Fuel 184, 10-17. doi:10.1016/j.fuel.2016.06.119

Meng, Q.-R., Wu, G.-L., Fan, L.-G., and Wei, H.-H. (2019). Tectonic Evolution of Early Mesozoic Sedimentary Basins in the North China Block. Earth-Science Rev. 190, 416-438. doi:10.1016/j.earscirev.2018.12.003

Meng, Y., Wang, X., and Chen, J. (2015a). Geological Evidence of the Cenozoic Tectonic Uplifting in Taihang Mountains - Apatite Fission Track Evidence from Well Qincan 1, 35. doi:10.3969/j.ISSN.1674-9057.2015.01.003

Meng, Y., Wang, X., Li, B., and Cai, Z. (2015b). Thermal Evolution History of Qinshui Basin in central North China Craton and Lithospheric Tectonic Evolution in Mesozoic and Cenozoic of Shanxi Plateau. Northwest. Geology. $48,159-168$.

Menzies, M. A., Fan, W., and Zhang, M. (1993). Palaeozoic and Cenozoic Lithoprobes and the Loss of $>120 \mathrm{Km}$ of Archaean Lithosphere, SinoKorean Craton, China. Geol. Soc. Lond. Spec. Publications 76, 71-81. doi:10.1144/GSL.SP.1993.076.01.04

M. G. Malusà and P. G. Fitzgerald (Editors) (2019). Fission-Track Thermochronology and its Application to Geology (Cham: Springer International Publishing). doi:10.1007/978-3-319-89421-8

MingGuo, Z., YanBin, Z., YanBin, Z., QiuLi, L., Yi, Z., HaiLong, H., et al. (2021a). Cratonization, Lower Crust and continental Lithosphere. Acta Petrologica Sinica 37, 1-23. doi:10.18654/1000-0569/2021.01.01

Pollastro, R. M. (1993). Considerations and Applications of the Illite/Smectite Geothermometer in Hydrocarbon-Bearing Rocks of Miocene to Mississippian Age. Clay s and Clay Minerals 41, 119-133. doi:10.1346/ccmn.1993.0410202

Ramseyer, K., and Boles, J. R. (1986). Mixed-Layer Illite/Smectite Minerals in Tertiary Sandstones and Shales, San Joaquin Basin, California. Clays and Clay Minerals 34, 115-124. doi:10.1346/CCMN.1986.0340202

Ren, J., Tamaki, K., Li, S., and Junxia, Z. (2002). Late Mesozoic and Cenozoic Rifting and its Dynamic Setting in Eastern China and Adjacent Areas. Tectonophysics 344, 175-205. doi:10.1016/S0040-1951(01)00271-2
Ren, Z., Xiao, H., Liu, L., Zhang, S., Qin, Y., and Wei, C. (2005). The Evidence of Fission-Track Data for the Study of Tectonic thermal History in Qinshui Basin. Chin.Sci.Bull. 50, 104-110. doi:10.1007/bf03184091

Ren, Z., Zhang, S., Gao, S., Cui, J., and Liu, X. (2006). Relationship between thermal History and Various Energy mineral Deposits in Dongsheng Area. Yimeng Uplift. Oil «Gas Geology. 27.

Shanxi, R. S. G. (1989). Regional Geology of Shanxi Provenance (In Chinese). Taiyuan, China: Shanxi Bureau of Geology and Mineral Resources.

Si, D. (2015). Petrology and Geochemistry of Mesozoic Ore-Bearing Dioritic Rocks in Talishan-Erfengshan Area, Southern Taihang Mountains.

Sun, B. L., Zeng, F. G., Xia, P., Zhu, Y. R., and Liu, C. (2018). Late Triassic-Early Jurassic Abnormal thermal Event Constrained by Zircon Fission Track Dating and Vitrinite Reflectance in Xishan coalfield, Qinshui Basin, central North China. Geol. J. 53, 1039-1049. doi:10.1002/gj.2942

Sun, Z. X., Zhang, W., Hu, B. Q., and Pan, T. Y. (2006). Features of Heat Flow and the Geothermal Field of the Qinshui Basin. Geophys 49, 130-134. doi:10.1002/cjg2.819

Sun, Z., Zhang, W., Hu, B., Li, W., and Pan, T. (2005). Geothermal Field and its Relation with Coalbed Methane Distribution of the Qinshui Basin. Chin.Sci.Bull. 50, 111-117. doi:10.1007/BF03184092

Tong, Y., Song, L., Zeng, S., Cheng, T., and Wei, Y. (2005). A New Method by Vitrinite Reflectance to Estimate Thickness of Eroded Strata. J. Palaeogeography(Chinese Edition) 7, 417-424.

Tong, Y., and Zhu, G. (2006). Some Important Problems of Using Vitrinite Reflectance to Recover Denudation. J. Oil Gas Technol. 28, 197-199.

Uysal, I., Mutlu, H., Altunel, E., Karabacak, V., and Golding, S. (2006). Clay Mineralogical and Isotopic (K-Ar, $\delta 18 \mathrm{O}, \delta \mathrm{D})$ Constraints on the Evolution of the North Anatolian Fault Zone, Turkey. Earth Planet. Sci. Lett. 243, 181-194. doi:10.1016/j.epsl.2005.12.025

Uysal, I. T. (2000). Clay-Mineral Authigenesis in the Late Permian Coal Measures, Bowen Basin, Queensland, Australia. Clays and Clay Minerals 48, 351-365. doi:10.1346/CCMN.2000.0480306

Uysal, I. T., Glikson, M., Golding, S. D., and Audsley, F. (2000). The thermal History of the Bowen Basin, Queensland, Australia: Vitrinite Reflectance and clay Mineralogy of Late Permian Coal Measures. Tectonophysics 323, 105-129. doi:10.1016/S0040-1951(00)00098-6

Uysal, I. T., Golding, S. D., and Thiede, D. S. (2001). K-ar and Rb-Sr Dating of Authigenic Illite-Smectite in Late Permian Coal Measures, Queensland, Australia: Implication for thermal History. Chem. Geology. 171, 195-211. doi:10.1016/S0009-2541(00)00247-3

Wang, Y., Deng, J., Wang, J., and Xiong, L. (2001). Terrestrial Heat Flow Pattern and Thermo-Tectonic Domains in the Continental Area of China. J. Graduate Sch. Chin. Acad. Sci. 18.

Wei, C., Qin, Y., Wang, G. G. X., Fu, X., Jiang, B., and Zhang, Z. (2007). Simulation Study on Evolution of Coalbed Methane Reservoir in Qinshui basin, China. Int J. Coal Geology. 72, 53-69. doi:10.1016/j.coal.2006.12.001

Wu, C., Qin, Y., and Zhou, L. (2014). Effective Migration System of Coalbed Methane Reservoirs in the Southern Qinshui Basin. Sci. China Earth Sci. 57, 2978-2984. doi:10.1007/s11430-014-4988-Z

Wu, F.-Y., Yang, J.-H., Wilde, S. A., and Zhang, X.-O. (2005b). Geochronology, Petrogenesis and Tectonic Implications of Jurassic Granites in the Liaodong Peninsula, NE China. Chem. Geology. 221, 127-156. doi:10.1016/ j.chemgeo.2005.04.010

Wu, F., Lin, J., Wilde, S., Zhang, X., and Yang, J. (2005a). Nature and Significance of the Early Cretaceous Giant Igneous Event in Eastern China. Earth Planet. Sci. Lett. 233, 103-119. doi:10.1016/j.epsl.2005.02.019

Wu, F., Xu, Y., Gao, S., and Zeng, J. (2008). Lithospheric Thinning and Destruction of the North China Craton. Acta Petrologica Sinica 24, 1145-1174.

Wu, L., Zhang, Z., and Zhang, Y. (1996). The Origin and Mineralization of Alkaline Rocks in the Shanxi Platform Anticline. Beijing: Science Press.

Xinhui, L., Yinshuang, A., Yaoyang, Z., Yongshun, C., and Jieyuan, N. (2017). Study of Lithospheric Structure in the central and Western North China Craton. Prog. Geophys. 32, 1458-1464.

Xu, W., Wang, D., Wang, Q., Pei, F., and Lin, J. (2004). 40Ar/39Ar Dating of Hornblende and Biotite in 655 Mesozoic Intrusive Complexes from the North China Block: Constraints on the Time of 656 Lithospheric Thinning. Geochimica 33, 221-231.

Xu, Y.-G. (2001). Thermo-tectonic Destruction of the Archaean Lithospheric Keel beneath the Sino-Korean Craton in china: Evidence, Timing and Mechanism. 
Phys. Chem. Earth, A: Solid Earth Geodesy 26, 747-757. doi:10.1016/S14641895(01)00124-7

Yan, G., Mu, B., and Zeng, Y. (1988). Characteristics of REE, Oxygen and Strontium Isotope Composition for the Zijinshan Alkaline RocksCarbonatite Complex in Shanxi Province. Acta Petrologica Sinica 4, 29-36. doi:10.1007/bf02018710

Yan, Y., Hu, X., Lin, G., Liu, W., and Song, Z. (2010). Detrital Zircon and Apatite Fission Track Data in the Liaoxi Basins: Implication to Meso-Cenozoic Thermo-Tectonic Evolution of the Northern Margin of the North China Craton. J. Earth Syst. Sci. 119, 541-551. doi:10.1007/s12040-010-0028-3

Yang, H. (2016). Geochronology of the Huyanshan Alkaline-Alkaline Complex in the Middle Segment of the Lvliang Uplift belt and its Tectonic Characteristics.

Yang, J.-H., Wu, F.-Y., Wilde, S. A., Belousova, E., and Griffin, W. L. (2008). Mesozoic Decratonization of the North China Block. Geol 36, 467. doi:10.1130/G24518A.1

Yang, P., Wu, G., Ren, Z., Zhou, R., Zhao, J., Zhang, L., et al. (2020). TectonoThermal Evolution of Cambrian-Ordovician Source Rocks and Implications for Hydrocarbon Generation in the Eastern Tarim Basin, NW China. J. Asian Earth Sci. doi:10.1016/j.jseaes.2020.104267

Yang, P., Wu, G., Nuriel, P., Nguyen, A. D., Chen, Y., Yang, S., et al. (2021a). In situ LA-ICPMS U Pb Dating and Geochemical Characterization of Fault-Zone Calcite in the Central Tarim Basin, Northwest China: Implications for Fluid Circulation and Fault Reactivation. Chem. Geol. 568, 120125. doi:10.1016/ j.chemgeo.2021.120125

Yang, J.-H., Xu, L., Sun, J.-F., Zeng, Q., Zhao, Y.-N., Wang, H., et al. (2021b). Geodynamics of Decratonization and Related Magmatism and Mineralization in the North China Craton. Sci. China Earth Sci. 64, 1409-1427. doi:10.1007/ s11430-020-9732-6

Yang, P., Ren, Z., Xia, B., Zhao, X., Tian, T., Huang, Q., et al. (2017a). The Lower Cretaceous Source Rocks Geochemical Characteristics and Thermal Evolution History in the HaRi Sag, Yin-E Basin. Pet. Sci. Technol. 35, 1304-1313. doi:10.1080/10916466.2017.1327969

Yang, Y., Zhao, J., Liu, C., Xue, R., and Yan, Z. (2017b). The Zircon LA-ICP-MS $\mathrm{L}-\mathrm{Pb}$ Ages and Geochemical Characteristics of Ta ' Ershan Intrusions, Southern Shanxi Province, and Their Geological Implications. Geol. Rev. 63, 809-821. doi:10.16509/j.georeview.2017.03.019

Yang, P., Ren, Z., Xia, B., Tian, T., Zhang, Y., Qi, K., et al. (2018). Tectono-Thermal Evolution, Hydrocarbon Filling and Accumulation Phases of the Hari Sag, in the Yingen-Ejinaqi Basin, Inner Mongolia, Northern China. Acta Geol. Sin. Engl. Ed. 92, 1157-1169. doi:10.1111/1755-6724.13597

Ying, J.-F., Zhang, H.-F., and Tang, Y.-J. (2011). Crust-mantle Interaction in the central North China Craton during the Mesozoic: Evidence from Zircon U-Pb Chronology, Hf Isotope and Geochemistry of Syenitic-Monzonitic Intrusions from Shanxi Province. Lithos 125, 449-462. doi:10.1016/j.lithos.2011.03.004

Yu, K., Ju, Y., and Zhang, B. (2020a). Modeling of Tectono-thermal Evolution of Permo-Carboniferous Source Rocks in the Southern Qinshui Basin, China: Consequences for Hydrocarbon Generation. J. Pet. Sci. Eng. 193, 107343. doi:10.1016/j.petrol.2020.107343

Yu, K., Ju, Y., and Zhang, B. (2020b). Modeling of Tectono-thermal Evolution of Permo-Carboniferous Source Rocks in the Southern Qinshui Basin, China: Consequences for Hydrocarbon Generation. J. Pet. Sci. Eng. 193, 107343. doi:10.1016/j.petrol.2020.107343

Zeng, Y., Fan, B., Liu, H., and Wang, C. (1999). An Analysis of the History of thermal Evolution Hydrocarbon- Generating and the Heat Source about Main Seam of Shanxi Formation in southeastern Shanxi Province. Sci. Geol.Sinica 34, 90-98.

Zhai, M., Zhao, L., Zhu, X., Zhou, Y., Peng, P., Guo, J., et al. (2021b). Late Neoarchean Magmatic - Metamorphic Event and Crustal Stabilization in the North China Craton. Am. J. Sci. 321, 206-234. doi:10.2475/01.2021.06

Zhai, M., Zhu, X., Zhou, Y., Zhao, L., and Zhou, L. (2020). Continental Crustal Evolution and Synchronous Metallogeny through Time in the North China Craton. J. Asian Earth Sci. 194, 104169. doi:10.1016/j.jseaes.2019.104169

Zhang, K.-J., Cai, J.-X., and Zhu, J.-X. (2006). North China and South China Collision: Insights from Analogue Modeling. J. Geodynamics 42, 38-51. doi:10.1016/j.jog.2006.04.004

Zhang, K.-J. (2012). Destruction of the North China Craton: Lithosphere FoldingInduced Removal of Lithospheric Mantle? J. Geodynamics 53, 8-17. doi:10.1016/j.jog.2011.07.005
Zhang, K.-J. (1997). North and South China Collision along the Eastern and Southern North China Margins. Tectonophysics 270, 145-156. doi:10.1016/ S0040-1951(96)00208-9

Zhang, K. (2002). Escape Hypothesis for North and South China Collision and Tectonic Evolution of the Qinling Orogen, Eastern Asia. Eclogae Geologicae Helv. 95.

ZhanLi, R., Qi, K., Kai, Q., RunChuan, L., JunPing, C., ZhiPeng, C., et al. (2020). Dynamic Background of Early Cretaceous Tectonic thermal Events and its Control on Various mineral Accumulations Such as Oil and Gas in the Ordos Basin. Acta Petrologica Sinica 36, 1213-1234. doi:10.18654/1000-0569/ 2020.04.15

Zhao, G., He, Y., and Sun, M. (2009). The Xiong'er Volcanic belt at the Southern Margin of the North China Craton: Petrographic and Geochemical Evidence for its Outboard Position in the Paleo-Mesoproterozoic Columbia Supercontinent. Gondwana Res. 16, 170-181. doi:10.1016/j.gr.2009.02.004

Zhao, G., Wilde, S. A., Cawood, P. A., and Sun, M. (2001). Archean Blocks and Their Boundaries in the North China Craton: Lithological, Geochemical, Structural and P-T Path Constraints and Tectonic Evolution. Precambrian Res. 107, 45-73. doi:10.1016/S0301-9268(00)00154-6

Zhao, X., Yang, Y., Sun, F., Wang, B., Zuo, Y., Li, M., et al. (2016). Enrichment Mechanism and Exploration and Development Technologies of High-Rank Coalbed Methane in South Qinshui Basin, Shanxi Province. Pet. Exploration Develop. 43, 303-309. doi:10.11698/PED.2016.02.1910.1016/s1876-3804(16) 30039-8

Zheng, Y., Xu, Z., Zhao, Z., and Dai, L. (2018). Mesozoic Mafic Magmatism in North China: Implications for Thinning and Destruction of Cratonic Lithosphere. Sci. China Earth Sci. 61, 353-385. doi:10.1007/s11430-0179160-3

Zhu, H., Huang, C., Ju, Y., Bu, H., Li, X., Yang, M., et al. (2021). Multi-scale MultiDimensional Characterization of clay-hosted Pore Networks of Shale Using FIBSEM, TEM, and X-ray Micro-tomography: Implications for Methane Storage and Migration. Appl. Clay Sci. 213, 106239. doi:10.1016/ j.clay.2021.106239

Zhu, R.-X., Yang, J.-H., and Wu, F.-Y. (2012). Timing of Destruction of the North China Craton. Lithos 149, 51-60. doi:10.1016/j.lithos.2012.05.013

Zhu, R., Fan, H., Li, J., Meng, Q., Li, S., and Zeng, Q. (2015). Decratonic Gold Deposits. Sci. China Earth Sci. 58, 1523-1537. doi:10.1007/s11430-015-5139-x

Zhu, R., and Xu, Y. (2019). The Subduction of the West Pacific Plate and the Destruction of the North China Craton. Sci. China Earth Sci. 62, 1340-1350. doi:10.1007/s11430-018-9356-y

Zhu, R., Zhang, H., Zhu, G., Meng, Q., Fan, H., Yang, J., et al. (2017). Craton Destruction and Related Resources. Int. J. Earth Sci. (Geol Rundsch) 106, 2233-2257. doi:10.1007/s00531-016-1441-x

Zhu, X.-Q. (2013). Tectonic Evolution of the central North China Craton since the Late Paleozoic- A Case Study of the Qinshui Basin.

Zhu, X.-Q., Zhu, W.-B., Ge, R.-F., and Wang, X. (2014). Late Paleozoic Provenance Shift in the South-central North China Craton: Implications for Tectonic Evolution and Crustal Growth. Gondwana Res. 25, 383-400. doi:10.1016/ j.gr.2013.04.009

Conflict of Interest: The authors declare that the research was conducted in the absence of any commercial or financial relationships that could be construed as a potential conflict of interest.

Publisher's Note: All claims expressed in this article are solely those of the authors and do not necessarily represent those of their affiliated organizations, or those of the publisher, the editors and the reviewers. Any product that may be evaluated in this article, or claim that may be made by its manufacturer, is not guaranteed or endorsed by the publisher.

Copyright $\odot 2021$ Liu, Ren, Yang, He, Smith, Guo and Wu. This is an open-access article distributed under the terms of the Creative Commons Attribution License (CC $B Y$ ). The use, distribution or reproduction in other forums is permitted, provided the original author(s) and the copyright owner(s) are credited and that the original publication in this journal is cited, in accordance with accepted academic practice. No use, distribution or reproduction is permitted which does not comply with these terms. 